Socio-Spatial Culture and Entrepreneurship:

Some Theoretical and Empirical Observations

Robert Huggins

School of Planning and Geography,

Cardiff University,

Glamorgan Building,

King Edward VII Avenue,

Cardiff,

CF10 3WA.

Email: hugginsr@cardiff.ac.uk

Phone: +44 (0) 2920876006

Piers Thompson

Nottingham Business School,

Nottingham Trent University,

Burton Street,

Nottingham,

NG1 4BU.

Email: piers.thompson@ntu.ac.uk

Phone: +44 (0) 1158482143

This is the peer reviewed version of the following article:

Huggins, R. and Thompson, P. (2016) 'Socio-spatial culture and entrepreneurship: some theoretical and empirical observations', Economic Geography, 92 (3), 269-300.

, which has been published in final form at:

http://dx.doi.org/10.1080/00130095.2016.1146075

This article may be used for non-commercial purposes in accordance with Wiley Terms and Conditions for Self-Archiving. 


\title{
Socio-Spatial Culture and Entrepreneurship: \\ Some Theoretical and Empirical Observations
}

\begin{abstract}
Entrepreneurship is increasingly acknowledged as an important factor underlying uneven economic geographies. Similarly, spatial patterns of entrepreneurship are increasingly considered to relate to the nature of the culture present within particular places. However, the nature of these relationships remains relatively unexplored, and this study addresses some of the gaps through both a theoretical and empirical examination of the association between socio-spatial culture and entrepreneurship. It develops the notion of community culture, and drawing on an analysis of data from localities in Great Britain it is found that a range of dimensions of socio-spatial community culture relating to social cohesion, collective action and social rules are found to be significantly associated with local entrepreneurial activity. Generally, localities in more economically developed regions are found to display more individualistic and diverse cultures. It is concluded that the findings represent a significant challenge for policymaking in less developed localities and regions, which generally have socio-spatial cultures high in communal and collective values but low rates of entrepreneurship.
\end{abstract}

Key words: Socio-spatial culture; Community culture; Institutions; Entrepreneurship; Localities; Regions.

JEL Classifications: L26, R12, Z1 


\section{Introduction}

Attempts to explain differing rates of entrepreneurship across places have usually found that economic factors only explain a degree of the variation, with any remaining significant dummy proxy variables within analyses often being attributed to cultural differences (Blanchflower 2000). Other studies have found that although rates of entrepreneurship are to some extent related to the stage of economic development of a nation (Blau 1987; Carree et al. 2002), differences across nations remain persistent over time, suggesting that other factors are also at play (Freytag and Thurik 2007). At a more territorial level, some studies have found that entrepreneurial and innovative activities tend to be positively related to economic growth (Beugelsdijk 2007), with a sub-national culture conductive to entrepreneurship and innovation being associated with outcomes such as rates of new firm formation (Davidsson 1995). However, relating unexplained ‘cultural residuals’ to particular cultural or institutional variables has often produced insignificant results or been hindered with issues of collinearity between the cultural and institutional variables (Freytag and Thurik 2007).

Studies that have attempted to develop specific measures of culture have often been inspired by Hofstede’s (1980) work on identifying the differentiating characteristics of national cultures as a means of analysing differing rates of entrepreneurship (Shane 1992, 1993; Mueller and Thomas 2001; Levie and Hunt 2005; Wennekers et al. 2007; Hechavarria and Reynolds 2009; Pinillos and Reyes 2011). In general, the vast majority of studies examining the role of culture in promoting entrepreneurship have made comparisons at the national level (Hayton et al. 2002). This ignores the potential role played by socio-spatial cultures, particularly given the differences found in entrepreneurial activity rates across not only nations but also regions (O’Farrell and Crouchley 1984; Whittington 1984; Audretsch and Fritsch 1994; Guesnier 1994; Hart and Gudgin 1994; Reynolds et al. 1994; Armington and Acs 2002; Bosma and Schutjens 2009, 2011; Trettin and Welter 2011; Spigel 2013), and 
their localities (Gould and Keeble 1984), which in many cases have been found to be persist over time (Mueller et al. 2008; Andersson and Koster 2011; Fritsch and Wyrwich 2014a).

Alongside the longstanding appreciation of the role of innovation, the complementary notion of entrepreneurship is increasingly acknowledged as an important factor underlying uneven economic geographies (Thornton and Flynn 2003; Audretsch and Keilbach 2004a; Wagner and Sternberg 2004; Malecki 2009; Sternberg 2009; Huggins and Williams 2011; Fritsch and Wyrwich 2014b). Therefore, entrepreneurial impacts relating to factors associated with socio-spatial cultural differences may have ramifications for the spatial scale that economic development policy should be ideally devised and implemented (Davidsson 1995; Fornahl 2003; Trettin and Welter 2011). Furthermore, culture is contested and negotiated on a constant basis (Heydemann 2008), suggesting that the rate and nature of local entrepreneurship and the societal aspects of local spatial cultures may be mutually reinforcing (Freytag and Thurik 2007).

It is generally acknowledged that factors relating to economic conditions (Blanchflower 2000) and the institutional environment (Acs et al. 2008; Boettke and Coyne 2009; Henrekson and Sanandaji 2011), especially those concerning the legitimacy of entrepreneurship (Etzioni 1987; Kibler et al. 2014) and the availability of social capital in the form of trust-based networks and the like (Westlund and Bolton 2003; Westlund et al. 2014), are an important determinant of rates of entrepreneurship. The aim of this study is to build upon these substantive understandings of the causes of differences in rates of entrepreneurship across places, and to provide a new conceptual measure of culture that is more encompassing than existing constructs such as social capital as a means of explaining such differences. To this end, the study seeks to add some new observations that complement existing explanations. 
The study develops and operationalizes a framework for examining localities in terms of entrepreneurship and their socio-spatial culture. Within the study, socio-spatial culture is conceptualized in terms of the 'community culture' of places, which is considered to refer to the broader societal traits and relations that underpin places in terms of prevailing mindsets and the overall 'way of life' within particular places. Clearly, the notion of 'community' is a slippery concept, and can relate to societal groupings that may, or may not, be place-based (Miller 1992; Storper 2008). In the case of this study, the notion of community culture principally refers to the social structure and features of group life within localities that can generally be considered to be beyond the economic life of such places. In essence, community culture consists of the overarching or dominant mindsets that underlie the way in which localities function, i.e. the ways and means by which individuals and groups within communities interact and shape their environment.

The key underlying questions the paper focuses upon are: (1) to what extent does entrepreneurship and community culture differ across localities?; (2) to what extent are differences in the rates and types of entrepreneurship across localities associated with the underlying community culture of these localities?; and (3) what types of community culture are associated with differing types of entrepreneurship across localities.

Drawing on data from Great Britain, the paper develops a number of indices of community culture at the local level. These are analysed in terms of their relationship with measures of entrepreneurship. In order to investigate the potential for community culture and entrepreneurship to act as forces in the adjustment and development of each other a multivariate approach is adopted with the variables taken as being endogenous.

The remainder of the paper is structured as follows. The next section outlines the main elements of the literature relating entrepreneurial activity to cultural factors, with a view to exploring the potential for the complementary development of a framework for examining 
the entrepreneurship and community cultural aspect of places. This is followed by a review of the methods and the analytical techniques used to empirically examine the relationship between the cultural and entrepreneurship variables generated. Following a presentation of the results stemming from the analysis, a set of conclusions and policy implications close the paper.

\section{Entrepreneurship and Socio-Spatial Culture}

In his seminal contribution, Tylor defines culture as 'that complex whole which includes knowledge, belief, art, morals, law, custom, and any other capabilities and habits acquired by man as a member of society' (Tylor 1871:1). At its most fundamental level, therefore, the concept of culture generally refers to the way in which people behave, often as a result of their background and group affiliation. Rather than concerning individual behavior it relates to shared systems of meaning within and across ascribed and acquired social groups (Hofstede 1980). Van Maanen and Schein (1979) suggest that culture can be defined by the values, beliefs and expectations that members of specific social groups come to share, while Hofstede (1980) refers to it as the collective programming of the mind, which distinguishes one group or category of people from another.

In their examination of the role of culture in economic thinking, Beugelsdijk and Maseland (2011) consider culture to be the collective identity of communities, suggesting that cultural analysis is traceable back to anthropological work such as Mauss’s (1925) cross cultural study of economic processes in The Gift. Anthropological approaches have often taken the perspective of highlighting how the culture of under-developed societies itself constrains this development. More economic approaches such as the work of Hirschman (1965) criticize the cultural constraint approach as being ethnocentrically biased, suggesting the question: can communities and societies have the 'wrong culture'? Others, such as 
Williamson (2000), view culture as the ultimate source of constraints. From a spatial perspective, therefore, culture can be considered as an element of the bounded rationality of places. As Fayolle et al. (2010) note, the connection between culture and development can be traced back to the seminal work of Landes (1953). Others trace it to the work of Weber (1930), which suggests an endogenous relationship between culture and development (Frederking 2002; Tabellini 2010; Huggins and Thompson 2015).

\section{Culture and Entrepreneurship}

Although research examining differing rates of entrepreneurial activity has been largely based around psychological and economic theories, there is growing recognition that factors relating to socio-spatial culture can provide valuable insights into related decision-making processes (Thornton et al. 2011). The interaction of culture and entrepreneurship has potential ramifications at a number of differing levels. Culture can legitimize the individualism associated with entrepreneurial activities, which may lead to economic development that benefits society at large (Weber 1930). Although entrepreneurship is often associated with the role of formal national institutions, the informal institutions more associated with community culture may conflict with the incentives and constraints stemming from national institutions, leading to unintended consequences (Thornton 1999).

Another perspective concerns the extent to which informal and formal institutions may be substitutes for one another, with a 'strong' community culture developing to fulfil the role of weak ineffective formal institutions (Durlauf and Fafchamps 2003). Where there is conflict, informal institutions associated with culture may play a greater role in determining behavior (North 1990). Given differing physical and industrial environments, there is no reason to assume that regional or local cultures will be uniformly compatible or incompatible with prevailing formal institutions (Rodríguez-Pose 2013). Policies developed to alter only 
formal institutions may, therefore, have only limited success, as the evolution of informal institutions is likely to be relatively slow (North 2005).

The links between the prevalence and nature of entrepreneurship with culture has long been recognized in the work of scholars such as Weber (1930), Schumpeter (1934) and McClelland (1961). Over the last thirty years or so, the number of studies that have attempted to incorporate the impact of culture into the study of entrepreneurship has increased significantly (Hayton et al. 2002; Huggins and Thompson 2015). Freytag and Thurik (2007) identify three routes through which culture may influence entrepreneurial activities. The first is the 'aggregate trait' view, whereby cultures that establish a population with strong entrepreneurial values will result in the creation of more entrepreneurs (Davidsson 1995; Uhlaner and Thurik 2007).

The second perspective is the 'legitimation' or 'moral approval' approach. Here, the prevailing culture makes entrepreneurial activities more acceptable and, as such, better rewarded (Etzioni 1987; Jack and Anderson 2002; Anderson and Smith 2007; Kibler et al. 2014). This means that although a population as a whole may be no more entrepreneurial than previously, more marginal individuals who formerly chose not to become entrepreneurs may now do so (Shapero and Sokol 1982). The third view concerns the so-called 'push' theory, whereby entrepreneurs and non-entrepreneurs have differing values and beliefs. The wider the gaps between the two groups the more likely it is that a latent entrepreneur will be pushed out of the mainstream labor force to establish their own business (Baum et al. 1993; Noorderhaven et al. 2004). Studies comparing entrepreneurs and non-entrepreneurs across cultures have found differences between these two groups regardless of the prevailing culture (McGrath et al. 1992; Baum et al. 1993). However, culture does seem to play a role in determining the extent to which these two groups differ (Baum et al. 1993), and therefore a 
role in determining the number of potential entrepreneurs within a population (Thomas and Mueller 2000; Mueller and Thomas 2001).

In general, it has been suggested that three main factors determine involvement in entrepreneurial activities: personal motivation; the institutional environment; and the economic and business environment (Nijkamp 2003; Minniti 2003). In a sense, culture may play a role in influencing all three factors by dictating socially accepted behavior, and therefore the motivations and economic objectives of an individual as part of a shared subjectivity (Casson 1982; Chell et al. 1991; Denzau and North 1994). Informal codes of behavior, conventions and business practices may be long lasting and are likely to shape an economy long after any formal institutions have been changed (North 1990; Lal 1998; Williamson 2000; Braunerhjelm and Henrekson 2013). Aoyama (2009) shows how the prevailing and accepted business norms of a region can influence attitudes towards, and involvement with, entrepreneurial activities, even within new sectors of economic activity with no previous tradition in a region. For those starting businesses in new sectors, the prevailing culture, operating through the entrepreneur's motivations, may determine the growth strategies pursued by entrepreneurs (Aoyama 2009).

Davidsson (1995) and Hayton et al. (2002) develop similar models to analyse culture's association with entrepreneurship, whereby culture is regarded not as a direct driver of entrepreneurship, but rather a moderator. Within these models, the key drivers remain the institutional context in terms of social, regulatory and legal systems (Bruton and Ahlstrom 2003; George and Prabhu 2000; Wyrwich 2012), as well as economic context, economic growth, industrial conditions and infrastructure (Davidsson 1995; Furman et al. 2002; Nelson 1993). It is the link between these key drivers and entrepreneurship that cultural values may operate upon, making entrepreneurship more or less acceptable, and increasing or decreasing 
the support available to entrepreneurs (Shane and Cable 2002; Casson and Della Giusta 2007).

Much of the empirical work concerning culture has followed from the seminal study of Hofstede (1980) and the four dimensions of culture he originally developed, namely: individualism-collectivism; uncertainty avoidance; power-distance; and masculinityfemininity. Hayton et al. (2002) suggest that the general nature of Hofstede's (1980) cultural dimensions means that they are not completely perfect for capturing the effect on entrepreneurial choices. Empirical studies using these dimensions as predictors of entrepreneurship have frequently encountered differing results depending on the groups of nations, time period, and measure of entrepreneurship investigated (Hayton et al. 2002; Hofstede et al. 2004). For example, Davidsson and Wiklund (1997) find limited evidence that entrepreneurship, as measured by new firm formation rates, is influenced by cultural variables in the particular case of regions in Sweden when accounting for the close links to other structural factors. Wennekers et al. (2007), on the other hand, find uncertainty avoidance to be linked to business densities across nations, whilst Shane (1993) finds innovation to be positively associated with individualism and negatively related to power distance, although these relationships are not persistent across differing periods of investigation. Along with low uncertainty-avoidance, Mueller and Thomas (2001) - using international data from students - find individualism to be associated with entrepreneurship through its connection with the likelihood of possessing an internal locus of control that makes entrepreneurship more likely.

Other measures of culture suggested to have an influence on entrepreneurship include the degree of post-materialism present in a society, whereby an emphasis is placed on elements such as personal development and self-esteem rather than material gain (Uhlaner and Thurik 2007) or satisfaction with life and/or the prevailing political economy 
(Noorderhaven et al. 2004). A difficulty in capturing empirical evidence concerning culture's influence on entrepreneurship is that as well as culture, formal institutional differences and macroeconomic influences are also likely to be caught in any measure (Beugelsdijk 2007; Foreman-Peck and Zhou 2013). Along with the pre-existing experience stemming from the entrepreneurial community, formal institutions may play an important part in determining the nature of the activities undertaken by entrepreneurs (Foreman-Peck and Zhou 2010; Rodríguez-Pose and Di Cataldo 2015).

Although some studies such as Foreman-Peck and Zhou (2013) and Wennekers et al. (2007) regard nations as possessing a homogenous culture, studies such as Beugelsdijk (2007) also find evidence of territorial differences. In Sweden, although regional cultural differences are not always large, those regions with values associated with entrepreneurship are found to display higher levels of start-up activities and higher entrepreneurial intentions (Davidsson 1995). As noted above, these differences may persist over time (Aoyama 2009), and may be reinforced by the activities undertaken and institutions developed to aid their accomplishment (Hall and Soskice 2001). In this respect, culture can enter economic decision-making processes, including involvement in entrepreneurial activities, in three main ways (Beugelsdijk and Maseland 2011), namely: as an exogenous factor, operating on preferences (Shane 1993); a source of constraints imposed to deal with imperfect information and constrained rationality (North 1990); or simply as deviations from the norm (Daly 1998). In relatively recent research, Foreman-Peck and Zhou (2013) find some evidence of cultural persistence based on the entrepreneurial prevalence rates of immigrant groups in the USA over the twentieth century, with more entrepreneurial groups in 1910 also more likely to be entrepreneurial in 2000. On the other hand, they also find evidence to suggest that globalization is leading to certain forms of cultural convergence (Foreman-Peck and Zhou 2013). 
In general, whilst the activities undertaken within a community may lead to cultural changes, they are more often a part of the framework for reinforcing the prevailing culture (Greif 1993, 1994; Aoki 2001). This suggests that although culture may influence the prevalence of entrepreneurs, entrepreneurial activities and the nature of these individuals and activities, such activities are themselves an influencing factor on future cultural development (Davidsson 1995; Freytag and Thurik 2007; Tran et al. 2009).

\section{Conceptualising and Measuring Community Culture}

With regard to the concept of community culture, it is important not to conflate the conception of 'community' with that of 'place', which are analytically distinct - although strong communities are often embedded in specific places (Miller 1992; Storper 2008). Like culture, the meaning of the term community is ambiguous, often referring to either a morally valued way of life or social relations in a discrete geographical setting (Agnew 1989, Miller 1992). The notion of community is associated with the nature of social ties and interaction, as well as the nature of the morality and behavioral norms present and practiced (Gerson et al. 1977; Smith 1999). A ‘stronger’ community culture, however, may in itself not always lead to positive outcomes. An over reliance on certain aspects of community culture, rather than formal institutions, can open a community up to the dangers of rent seeking by individuals at the expense of a group as a whole, as well as the existence of insider-outside problems, whereby the existing community benefits at the expense of those who are not members (Trigilia 1992; Farole et al. 2011).

Needless to say, conceptualising and measuring socio-spatial culture is a somewhat difficult and controversial undertaking. Isolating particular measures from indicators that could be considered the outputs or outcomes of territorial evolution presents a range of issues in terms of identifying potential causality and endogeneity. With these factors in mind, the 
current study seeks to establish an original typology of socio-spatial community culture as a means of configuring a series of indicators allowing broad measures of different facets of such culture to be measured. In the remainder of this section we draw on the relevant literature as means of establishing this framework.

Perhaps the fundamental starting point for any conceptualization of culture is Weber's (1930) enduring notion of the 'work ethic' and attitudes to economic participation. Coupled with this, education is closely considered to be an important cultural feature of places (Tabellini 2010). Attitudes toward work and education are in many ways related to the extent to which individuals place a strong emphasis on self-sufficiency and making a contribution to society (Gregson et al. 1999; Brennan et al. 2000; Becker and Woessmann 2009). However, in order to accomplish this, the correct investments in human capital must be made and this requires a long-term orientation. Societies and communities often face a constant struggle to transmit values relating to employment and education from one generation to the next (Wyrwich 2015), with the failure to do so leading to the development of institutions that are more suited to economies with fewer incentives for activities such as entrepreneurship (Vaillant and Lafuente 2007; Bénabou and Tirole 2006). Given this, it is suggested that factors related to engagement with education and work may represent one dimension of community culture. Clearly, quantitatively capturing this at the local level is far from easy, but in terms of work ethic, economic participation rates are a useful guide. As Durand (1975) argues in his seminal work on labor force participation, whilst participation rates may vary in the short-term as a result of demand and supply factors, in the long-term these rates are determined 'within a framework of culture', and as these cultural frameworks differ across societies it can be expected that economic participation rates will vary as a result. In this case, we utilize male economic activity rates, with females rates associated with another cultural component defined below due to the specific and different set of cultural factors and values 
that have been found to be associated with female labor market engagement (Stam et al. 2014). As for engagement with education measures, the proportion of the local population with no formal education and rates of school absenteeism are utilized.

In recent years, a growing range of studies have identified the rate of cultural diversity, particularly in ethnic and religious terms, as a factor determining entrepreneurship and economic development at the local and regional level (Ottaviano and Peri 2006; Lee 2011, 2015; Nathan and Lee 2013; Kemeny 2014; Rodríguez-Pose and Hardy 2015). This raises the issue of whether more socially diverse or cohesive local communities are associated with higher rates of entrepreneurship. The cultural aspect of social cohesion, related to greater homogeneity and bonding of the community, may be positively linked to entrepreneurship through greater trust and support (Davidsson and Honig 2003). This relates to Durkheim's (1893) notion of 'mechanical' and 'organic' solidarity social cohesion, whereby trait similarities and interdependence amongst individuals result in a perceived unity, togetherness and less likelihood of exclusion. The trust formed within a community may be strongly influenced by the extent to which there is a cohesive and uniform group that makes up the majority of a community’s population. Some evidence has suggested that group membership symbolizing this is positively correlated with economic factors (Knack and Keefer 1997; Zak and Knack 2001; Beugelsdijk et al. 2004; Guiso et al. 2004). Equally, if groups within a community are deeply divided this may have negative economic impacts, as generalized trust will be reduced (Easterly and Levine 1997; Aghion et al. 2004). However, there is a potential for groups to be too inwardly looking where bonding ties are strong, limiting access to new ideas from outside the community (Portes and Landolt 2000; Florida 2002; Levie 2007). Based on the above, we suggest that an important dimension of the community culture of a locality can be conceptualized in terms of the social cohesion or diversity present. Although not uncontroversial, available measures at the local level that 
have been utilized by others, and which are adopted here, consist of: ethnic similarity; religious similarity; migration rates; proportion of the population born in their nation of residence and the proportion of the population perceiving themselves as a national of the resident country.

Hofstede's (1980) seminal work on establishing a typology of national cultures introduced the notion of the femininity or masculinity of these cultures, with masculine cultures considered to be more competitive and materialistic than their feminine counterparts, which are more caring and harmonious in their outlook. Although to some extent this account could be considered stereotypically outdated, the idea of cultural femininity endures (Shneor et al. 2013), and whilst individualist and competitive societies may achieve greater economic success, this is not necessarily the case if competition is too great. Conflict and violence can result, with fractures appearing within the community. The market offers an opportunity for this competition to be used in a less destructive manner than could be the case. However, there is still the potential for resources to be wasted, e.g. the desire to possess certain goods without regard for the generation of negative externalities on others (Hirsch 1977), or where higher income levels do not necessarily lead to greater well-being (Easterlin 1974). This means that although many of the traits associated with entrepreneurial and business activities are often thought to be masculine in nature (Bennett and Dann 2000; Bruni et al. 2004), lower working hours and greater flexibility may also be beneficial (Hundley 2001). Social norms and expectations may result in contrasting effects on male and female welfare, as differing domains take precedence for each gender (Parasuraman et al. 1996). These factors indicate that cultural attributes associated with femininity and caring attitudes may be related to entrepreneurship, with it being generally acknowledged that the engagement of women in entrepreneurship is linked to prevailing cultural influences (Carter et al. 2012; Langevang et al., 2015). In terms of indicators, the engagement of females in the labor market is clearly 
paramount, and available measures at the local level consist of female economic activity rates and rates of female part-time employment (in places where part-time employment represents a greater proportion of all female employment this equates to more feminine cultural values). Furthermore, another useful measure is the rate of unpaid care provision within a locality, which is an activity that is predominately undertaken by women.

Rodríguez-Pose and Storper (2006) note the importance of adherence to social rules for coordination purposes. Within communities, social conventions reinforced by reputational effects are often required as coordination tools for maintaining accepted social norms (Lorenzen 2007). There is a danger that if unchecked subversive activities could become the 'new' social norm and be seen as acceptable forms of behavior (Kearns and Forrest 2000). Where this is the case, the level of trust within the community is likely to fall, plus it may be harder to form bridging ties to other communities, as individuals from within these communities are likely to suffer from a stigma effect (Atkinson and Kintrea 2001). Although there is evidence from studies such as Noorderhaven et al. (2004) that creativity can often be an outlet where social rules are too constraining, there is also evidence that adherence to social rules, such as respect for authority and traditional values increases the level of trust present, allowing interactions for mutual benefit, such as in the case of entrepreneurship (Hechavarria and Reynolds 2009). In particular, social conventions and reputation are important coordination tools for information gathering activities (Lorenzen 2007). Adherence to social rules, therefore, is an important means of conceptualising these aspects of community culture. At the local level, the indicators most relevant to capturing such adherence or otherwise consist of engagement in criminal or deviant behavior, and in this case the measures employed are rates of non-sexual violent crimes; crimes by deception; alcohol related deaths and underage conceptions. These indicators relate to the growing acknowledgement that the cultural values associated with deprivation, such as crime and anti- 
social behavior, may have consequences for the rates of entrepreneurship within a particular place (Slack 2005; Zhang and Arvey 2009; Brennan et al. 2000; Obschonka et al. 2013).

Finally, despite recent advances it is still unclear whether a more individualistic or collective cultural approach is more conducive to entrepreneurship, with there being potentially benefits from both cultural systems (Wennberg et al. 2013). Within more individualistic systems, although less trust may be built up within the community, it may possess a greater propensity toward market activities. More collective systems, on the other hand, can create greater trust within groups, but any 'aggressive' tendencies must usually be directed outwards at other groups (Greif 1994; Casson 1995; Ettlinger 2003; Lang and Roessl 2011). Closely associated with collective action is the desire for equality or greater equity, and where this is the case the rewards achieved by successful entrepreneurs may be viewed less positively by the remainder of the community. Community enterprises may be viewed as one way of boosting all community members' welfare, providing an equity driven collective approach, which is twinned with incentives for greater enterprise (Casson 1995; Johnstone and Lionais 2004). This suggests that the notion of collective action is a means of conceptualising the extent to which culture is more attuned to cooperative, as opposed to individualistic, action. Indicators of collective action at the local level are relatively sparse, but the two employed here are the proportion of votes cast being for left of centre parties at national political elections and rates of trade union membership.

In summary, the above has identified the following dimensions of community culture: (1) engagement with education and work; (2) social cohesion; (3) femininity and caring attitudes; (4) adherence to social rules and (5) collective action. In the following section we show how the aforementioned indicators are implemented in the empirical analysis, along with details regarding the other measures employed in this analysis. 


\section{Methods for Empirical Analysis}

The empirical analysis utilizes data for 2010, with the localities covered consisting of those in all nine Government Office Regions of England plus the two devolved regions of Scotland and Wales in Great Britain. These localities are comprised of a mix of English and Welsh local authority districts, unitary authorities, metropolitan districts, London Boroughs, and Scottish council districts. This provides 380 non-overlapping areas covering the whole of Great Britain. However, the outlier of the City of London is excluded along with the very small unitary authority of the Isles of Scilly and four localities in Scotland, resulting in 374 usable observations ${ }^{1}$.

The first step of the methodology consists of the operationalization, measurement and development of indices for the cultural attributes of localities. In order to operationalize each cultural component Principal Components Analysis (PCA) is used to isolate the common variation in each group of indicators and the weighting of individual components (the results of the PCA are shown in Appendix Table A1) ${ }^{2}$. Where more than one component was extracted from the data, based on Kaiser's (1960) criterion of selecting those factors with an eigenvalue above 1 , the first component accounting for the largest proportion of variance was

\footnotetext{
${ }^{1}$ Both of these localities are extremely small in terms of area and population. In the case of the City of London it is the centre of the financial sector and therefore has a GVA per capita much greater than other local authorities. The Isles of Scilly are remote from the British mainland and have an economy heavily dependent on tourism. For both of these localities there are also considerable problems with missing data for each. Four Scottish local authorities also have to be excluded as the Northern Police Force does not conduct a satisfaction survey as utilized to capture the quality of formal institutions present (please see below). The four excluded Scottish council districts are Highlands, Orkney Islands, Shetland Islands and Eilean Siar.
}

${ }^{2}$ In order to ensure that the measures were consistent with the cultural components they were capturing, and the other measures included in the same components, it was necessary to utilize the inverse of some measures. For example, school absenteeism is more a reflection of lack of engagement with education and work, whilst measures of educational attainment would be the opposite. 
utilized, following an approach similar to that used by Tabellini (2010) to generate measures of institutions and culture. The maximum likelihood approach adopted utilizes a varimax orthogonal rotation to provide greater clarity with regard to the interpretation of the different components extracted to ensure that the desired cultural component is captured. The scores are produced using the Anderson-Rubin approach that is best suited when non-correlated factor scores are required, allowing for the possibility of including multiple components if appropriate (Tabachnick and Fidell 2007).

The correlation between individual measures is presented in Table A2. There are some complementarities in terms of the aspects of community culture formed in localities, which is to be expected given that culture and institutions may evolve to support the social and economic activities of communities, as argued in the varieties of capitalism literature (Hall and Soskice 2001), and evidenced by the clusters of historically linked nations found by Hofstede (2001) to have similar combinations of cultural dimensions. In particular, engagement with education and work is positively linked to feminine and caring activities, and negatively linked to collective action, with feminine and caring activities positively associated with adherence to social rules. However, these relationships are far from perfectly correlated, suggesting that whilst different aspects of culture are correlated, they are relatively distinct from one another. As a test of this, a PCA of the five cultural components was undertaken with the cultural components failing to load on a single component, with the first component extracted being able to only capture 48 percent of the variance. As well as combined measures of the cultural components, we also test individual measures that may reflect the cultural components. The measures chosen are those that load most strongly onto the first components extracted and have more variation accounted for: secondary school absenteeism (engagement with education and work); ethnic similarity (social cohesion); proportion of female employment which is part-time (feminine and caring activities); crimes 
by deception (adherence to social rules); proportion voting for left of centre parties (collective action).

\section{Measuring Entrepreneurship}

Although imperfect and not capturing entrepreneurial activity within existing enterprises, studies such as Audretsch and Keilbach (2004b) suggest that start-ups are the ultimate manifestation of the entrepreneurship capital or potential of a locality. Audretsch and Thurik (2004) assume that business creation, as a source of competition, increases the need to boost productivity, and to achieve this innovation is promoted. In a similar fashion to El Harbi and Anderson (2010), we include a measure of new firm formation to account for new entrepreneurial activity, or what Freytag and Thurik (2007) refer to as dynamic measures of entrepreneurship. New firm formation rates are scaled by population. This is consistent with the labor market approach, which acknowledges that businesses are started by individuals (Audretsch and Fritsch 1994).

Alongside this more dynamic perception of entrepreneurship, the analysis seeks to measure existing entrepreneurial activity, reflecting those measures described by Freytag and Thurik (2007) as static measures of entrepreneurship. This is often associated with the economic structure of the business community, in terms of industry breakdown and size of establishments (Shane 1993; Audretsch and Keilbach 2004a). The existing entrepreneurial community is generally considered to influence the new firms created in terms of both their numbers and type (Elfenbein 2010). Some studies have identified the number of small businesses as a key factor in this respect, operating as a source of role models (Davidsson 1995; Verheul et al. 2001; Fritsch and Mueller 2005; Mueller 2006; Lafuente et al. 2007). In this study, we consider the presence of firms that fall into the small and medium sized enterprise category (0 to 249 employees). This includes micro firms (less than 10 employees) 
which can be associated with casual employment (Foreman-Peck and Zhou 2013). However, as those running small businesses may act as role models for latent entrepreneurs (Mueller 2006; Fotopoulos 2014), we still include these businesses within the measure. As with new firm formation, the presence of SMEs is scaled by the population of the locality. It is important to note that existing (static) and more dynamic measures of entrepreneurship may be closely linked, since the existing industry structure, in terms of industrial mix and presence of small firms, has been found to be associated with new firm formation rates (O’Farrell and Crouchley 1984; Davidsson 1995). Although both new and existing entrepreneurship will include those described as economically active, given the role of cultural influences in determining these levels of participation (Durand 1975), it is only natural to assume that any intention to start a business is preceded by the initial decision to economically participate. Calculations were also run for the entrepreneurship measures scaled by the economically active population rather than working age population, with the results remaining largely unaffected - these are not reported in full, but any findings of key importance are noted where pertinent.

Structural factors identified as being influences on local start-up rates can be of both a pull and push related nature. Pull style factors include: the density of small firms; total population; population density; prior population growth; and prior declines in unemployment. The first of these relates to the role models provided by existing small business owners, with the latter four relating more heavily to increases in local aggregate demand (Davidsson 1995). Push factors relate more to a lack of alternative employment, with measures such as unemployment levels and spending on development support per capita capturing these (Davidsson 1995).

As many new firms serve local markets when first formed (Thomas et al. 2013), local demand conditions are likely to have an important influence on entrepreneurial activity. 
Factors that are likely to represent improving demand conditions are population and income growth. Both of these would be expected to be associated with individuals being pulled into entrepreneurship (Lee et al. 2004; Armington and Acs 2002). Local population growth is measured for the period 2004 to 2010 to capture the trajectory of the population leading up to the period of study. This data is drawn from the NOMIS mid-year population data.

The growth rate of mean gross weekly income between 2008 and 2010 is used to capture income changes. This data is drawn from the Annual Survey of Hours and Earnings (ASHE). A large number of studies have found a relationship between unemployment and new firm formation (Santarelli et al. 2009). This relationship could theoretically be either positive or negative. The unemployed may experience a recession push into entrepreneurship in order to create their own jobs (Evans and Leighton 1989). Alternatively, higher unemployment may reflect weaker demand conditions reducing the 'prosperity pull', resulting in a negative relationship (Storey and Johnson 1987). Empirical studies provide mixed evidence (Thurik et al. 2008). As income and population growth are likely to capture pull factors, the measure of unemployment included here is the difference between the unemployment rate in 2010 (proportion of the population claiming Job Seekers Allowance and other associated benefits, based on NOMIS data) and that of the preceding five years, in order to better capture any shorter run push associated with increases in unemployment.

The second group of variables included are those associated with industry structure. Rocha (2013) provides evidence from Germany that entrepreneurship is greater in clusters as the networks and knowledge spillovers present provide opportunities for firm formation. Although imperfect, we follow Fotopoulos (2014) in using measures of industry diversity and industry specialization to account for these factors. Industry diversity is based on Theil's 
(1972) entropy measure, whereas a relative specialization index is used to capture industry specialization $^{3}$.

\section{Measuring Institutions}

It is likely that the quality of formal institutions will help boost economic performance, including supporting the existing business community and encouraging new firm formation (Knack and Keefer 1995; Mauro 1995; Mo 2001). It is these formal institutions that ensure contractual obligations and rules of law are upheld. However, it is possible that the level of

${ }^{3}$ The industrial diversity measure drawn from Fotopoulos (2014) is based on Theil's (1972) diversity entropy measure:

$$
H_{l}=\sum_{i}\left(p_{l i} / p_{l}\right) \ln \left(p_{l} / p_{l i}\right)
$$

Where $p_{l i}$ is the proportion of all employment in Britain found in industry $i$ in locality $l\left(E_{l i}\right)$ :

$$
p_{l i}=E_{l i} / \sum_{l} \sum_{i} E_{l i}
$$

$p_{l}$ is the share of all employment in Britain found in locality $l$ :

$$
p_{l}=\sum_{i} p_{l i}
$$

A value of 0 indicates the presence of just one industry in the locality, higher values represent a more diverse industrial employment. In order to bound the diversity value within an interval $[0,1] \mathrm{H}_{l}$ is divided by the natural $\log$ of the number of industries considered. The division of 15 industries employed by Fotopoulos (2014) is applied. Data on employment by industry is drawn from the Annual Business Inquiry for 2004 (ABI).

The industrial specialization measure is formulated as follows:

$$
S P E C_{l}=1 / 2 \sum_{i}\left(E_{l i} / E_{l}-E_{n i} / E_{n}\right)
$$

Where $E_{l}$ is all employment in the locality, $E_{n i}$ is all employment in Britain within industry $i$ and $E_{n}$ is all employment in Britain. The index has a value of 0 when the locality has the same industrial structure as that found in Britain as a whole. It takes a value of 1 when only one industry is present in the locality. 
entrepreneurship in a locality may not alter or even decline as institutions strengthen due to the impact upon rates of informal entrepreneurship, although higher quality formal entrepreneurship is likely to rise (Autio and $\mathrm{Fu}$ 2015). An institutional environment that supports knowledge spillovers and venture finance may be particularly important in encouraging entrepreneurial activities associated with innovation and job creation (Stenholm et al. 2013). Furthermore, institutions may play a role in determining the nature that entrepreneurial activities take, and the extent to which they may be productive, unproductive or even destructive (Baumol 1990).

As with studies that have sought to assess the role of formal institutions in promoting innovation (Rodríguez-Pose and Di Cataldo 2015), it would also appear pertinent to include the role of these institutions within an analysis of entrepreneurship. There are a number of measures of the quality of institutions at the national level, such as Transparency International's Corruption Perception Index (CPI) and the International Country Risk Guide (ICRG). However, studies such as Charron et al. (2014) recognize that variations in institutional quality within nations can be considerable, and in response they have developed regional measures of the quality of government for EU regions based on the World Bank's Governance Indicators national measures (Kaufmann et al. 2009) and a citizen survey gathered at the regional level. The citizen survey captured ratings of three public services: education, healthcare and law enforcement in terms of their quality, impartiality and corruption.

Equivalent measures are not available at the local level, but as a means of capturing the potential for variation across local authority areas we extend the approach of Charron et al. (2014). As it is not possible to utilize social surveys at the local level, we measure fluctuations through satisfaction surveys of the police (Home Office Statistics and Scottish Policing Performance Framework), General Practitioners of Medicine (NHS England, 
National Survey for Wales, 2013-14 - Health - experience of GP services and Scottish Health and Care Experience Survey) alongside other measures of the quality of institutions such as complaints against the police (Her Majesty’s Inspectorate of Constabulary and Scottish Policing Performance Framework), average primary school class size (Department for Education, Schools Census results and Summary Statistics for Schools in Scotland), and the proportion of schools rated as good or above (Office for Standards in Education, Children's Services and Skills (Ofsted), Estyn and School Estate Statistics). ${ }^{4}$

The natural logs of each of these measures is taken and an index is created with 100 representing the local authority area average. An overall index is established by taking a weighted average of these measures. The weights are chosen to ensure that all three elements of the institutions receive equal weighting, i.e. both measures of police quality are weighted $1 / 6$, both of the education quality measures are weighted $1 / 6$ and the health quality measure is weighted $1 / 3$. To ensure that the variation at the regional level is consistent with that found by Charron et al. (2014), the local authority index is adjusted so that the national average and variance of the regional values is identical to their quality of government measures. This means that the local institutional measures are restricted to capturing variation within a region rather than across regions. To achieve this, the ratio of the local authority area index to the average local authority index within the same region is found. The Charron et al. (2014) regional quality of government measure is then multiplied by this ratio.

The preceding subsections have outlined the motivation for using each of the indicators outlined to capture the determined aspects of community culture, as well as

\footnotetext{
${ }^{4}$ For the police and health measures these are captured at the police force and health team level each of which includes a number of local authorities. Likewise the education measures are captured at the unitary authority and county level. This means not all variation in the quality of these institutions is captured across local authority areas. However, due to the underlying nature of the decision-making processes of these institutional actors, it is probable that more of the variation will be across these police forces, health teams and counties rather than within them.
} 
existing and new entrepreneurship, and institutions. These are summarized in Table 1 in turn. We acknowledge that the focus on the localities limits the availability and choice of indicators. However, the indicators have been selected on the basis of prior studies and their ability to reflect the key influences on the relationships between community culture, entrepreneurship and institutions.

\section{PLEASE INSERT TABLE 1 ABOUT HERE}

\section{Mode of Analysis}

The observations available at the local level enable multivariate analysis to be conducted, with controls for differences in economic conditions, industrial structure and formal institutions included as discussed in the preceding section. The impact of the five community cultural indices upon existing and new entrepreneurial activity can be explored using simple ordinary least squares regressions. However, this will not fully capture the bidirectional relationships that may exist between community culture, formal institutions and entrepreneurship. In order to accommodate this possibility, the relationships need to be estimated as a system of regressions. Here each of the four key factors - community culture, formal institutions, new entrepreneurial activity and existing entrepreneurial activity - are treated as endogenous and determined by the other three. To achieve this, a three stage least square regression approach is adopted to estimate the following relationships:

$$
\begin{aligned}
& Y_{B C, i}=\beta_{1}+\beta_{2} Y_{E C, i}+\beta_{3} Y_{F I, i}+\beta_{4} Y_{C C, i}+\gamma_{1} X_{i}+\lambda_{1} Z_{1, i} \\
& Y_{E C, i}=\beta_{5}+\beta_{6} Y_{B C, i}+\beta_{7} Y_{F I, i}+\beta_{8} Y_{C C, i}+\gamma_{2} X_{i}+\lambda_{2} Z_{2, i} \\
& Y_{F I, i}=\beta_{9}+\beta_{10} Y_{B C, i}+\beta_{11} Y_{E C, i}+\beta_{12} Y_{C C, i}+\gamma_{3} X_{i}+\lambda_{3} Z_{3, i} \\
& Y_{C C, i}=\beta_{13}+\beta_{14} Y_{B C, i}+\beta_{15} Y_{E C, i}+\beta_{16} Y_{F I, i}+\gamma_{4} X_{i}+\lambda_{4} Z_{4, i}
\end{aligned}
$$


Where $Y_{B C, i}, Y_{E C, i}, Y_{F I, I}$ and $Y_{C C, i}$ represent, respectively, existing entrepreneurial activity, new entrepreneurial activity, formal institutions, and the community culture of locality $i$. Each of the four factors is hypothesized as being influenced by the other three. There are also a common set of locational characteristics, $X_{i}$, which influence entrepreneurial activities, community culture and institutions. In addition, there are also locational factors that are specific to each element $Z_{j, i}$. For the purposes of estimating the system, the factors specific to entrepreneurial activities, culture and institutions are important in identifying the equations. The three stage least squares estimator is used, which operates by using the exogenous variables $\left(X, Z_{j}\right)$ to create instruments to represent any endogenous variables appearing as dependent variables in one equation and on the right-hand side of another equation (Zellner and Theil 1962).

A consistent estimate of the covariance matrix of equation disturbances is produced from the residuals of the estimation for each equation, which is then used to perform a generalized least squares estimation (Greene 2003). This approach means that each element of community culture can only be examined in isolation, as it would be unlikely that exogenous variables could be theoretically found that relate to just a single element to identify the eight required equations.

The common factors included in the equations are those noted in the previous section, i.e. those relating to aggregate demand and industrial structure in the local economy. To identify the existing entrepreneurial activity equation, the proportion of the workforce employed as managers and professionals is included, as these represent inputs into the knowledge creation process of existing businesses (Huggins and Izushi 2007). The presence of these positions will relate to the types of industry present in the local area. Also, the managerial presence within the workforce represents the human capital required for the production of goods and services, especially where managerial talent is required to coordinate 
resources within industries with more entrepreneurial and less standardized production (Acs et al. 2009). A negative relationship may exist between entrepreneurship and professional employment as much of this employment is likely to be created in larger organizations (Hoffman et al. 1998; Acs et al. 2009; Qian et al. 2013; Gross et al., 2013).

The new entrepreneurial activity equation includes the proportion of the population in the prime age group (35 to 44 years) as this is where studies have found the propensity to start new enterprises to be highest in the UK (Harding 2007). This reflects the combined effect of two opposing forces leading to an inverted U-shaped relationship between new entrepreneurship and age (Kim 2007). Studies consistently find that latent entrepreneurs prefer to work for others to gain resources such as experience, finance and network connections before starting enterprises (Baum and Silverman 2004; Kwong and Thompson 2015). However, the ability to make a return from entrepreneurship also recedes as age increases, with the time to recoup any investments declining (Lévesque and Minniti 2006). Other variables such as the provision of start-up equity finance are not available at the appropriate level of disaggregation, and even at the regional level display extreme volatility from year to year.

The quality of formal institutions in a locality is assumed to be, at least in part, related to the demands placed upon them. Rodrik (2000), for example, notes the problems that can occur when regulatory institutions are swamped by increased financial freedom, or where conflict over resources imposes demands on conflict management institutions. Although there may be greater variation in public sector efficiency due to the varying quality of institutions (Afonso et al. 2005), where demand is higher performance may fall unless compensated for by improved quality. In order to capture the demand for healthcare, the proportion of the working age population suffering from poor health is included (National Census data). The demands on the education system as a whole are captured by the number of full-time pupils 
and students present (National Census data). No equivalent measure is available for the demands placed on the justice system.

Existing studies depict culture as displaying a high level of persistence and evolving more slowly through time than more formal institutions (Roland 2004; Foreman-Peck and Zhou 2013; Licht et al. 2007). This is because social norms and beliefs adjust incrementally rather than overnight, as may be the case at times with political institutions. Studies suggest that the basic values of individuals alter little once adulthood is reached (Baker et al. 1981), so that generations have collective memories (Schuman and Scott 1989). As community culture may be more slowly evolving among older age groups (Jones 2006), the proportion of the older generations in the population (aged 65 or over) is included in the regression. The simple correlations between all dependent and independent variables are reported in Table A3, and in the case of the separate indicators used as alternative representations of community culture in Table A4.

\section{Results}

In order to begin the analysis it is useful to examine the extent to which there are any broad correlations between measures of community culture and entrepreneurship without controlling for other variables that may have an impact on this association. To aid this, Figure 1 presents a series of scatter charts illustrating the relationship between each dimension of community culture and both new and existing entrepreneurship. First, in terms of the association between community culture as measured by the propensity to engage with education and work, there is a generally positive relationship with both new and existing entrepreneurship, suggesting that localities with a greater engagement are likely to experience higher rates of entrepreneurship (Gregson et al. 1999; Brennan et al. 2000). Interestingly, it is 
those localities with lower levels of existing and new entrepreneurship that show the most variation in engaging with education and work.

\section{PLEASE INSERT FIGURE 1 ABOUT HERE}

There is a relatively strong negative association between social cohesion and new entrepreneurship. This begins to suggest that new firm formation and younger entrepreneurial firms are likely to be more prevalent within local economies that are relatively diverse and open (Florida 2002; Saxenian 2006; Levie 2007; Nathan and Lee 2013; Rodríguez-Pose and Hardy 2015). In particular, localities in leading regions such as London and South East England generally have a relatively low social cohesion index score, as one would expect given the higher ethnic diversity found in these regions, as well as a relatively high new entrepreneurship rate. Interestingly, however, the relationship is weaker for rates of existing entrepreneurship, which could indicate that social cohesion/diversity is more strongly related to new firm generation than local economic structure in terms of the types of firms within a particular locality.

The relationship between femininity and caring activities and existing entrepreneurship is relatively neutral. However, a more negative association is found for measures of new entrepreneurship. Although the regression analysis presented later will examine in more detail the robustness of this relationship, it appears to indicate that localities with a community culture high in traits relating to caring and femininity may be less prone to generating high rates of new entrepreneurship.

The relationship found between measures of social rules adherence and entrepreneurship potentially means that crime rates and the like are negatively associated with entrepreneurship, which is allied to those scholars who have used a social capital lens to 
examine its influence on economic development and entrepreneurship (Helliwell and Putnam 1995; Knack and Keefer 1997; Portes and Landolt 2000). As maybe expected, adherence to social rules is positively associated with rates of existing entrepreneurship. However, this pattern is much less clear for new entrepreneurship.

Finally, Figure 1 shows that both measures of entrepreneurship are negatively associated with rates of collective action and equality. This is consistent with the prevailing view that the competitive nature of entrepreneurship may make it more natural and acceptable in atomistic cultures (Mueller and Thomas 2001). Other models of entrepreneurship embracing collective activity may exist (Casson 1995), but they do not appear to dominate at the present point in time.

Overall, notable spatial differences are found across localities in the UK's core economic regions - i.e. London, the South East of England and the East of England - and localities in more economically peripheral regions. In general, localities in core regions appear to display a stronger engagement with education and work, and a greater commitment to social rules. However, these localities are also found to both more diverse and 'masculine' in nature, and generally display less evidence of collective activities.

The pattern of local community culture differences across regions is to a large extent understandable given their differing social and economic histories. For example, localities in more peripheral regions, with their legacies of labor intensive heavy industry, may be expected to embrace collective activities to a much greater extent. Similarly, London has long been the gateway to the UK, and with greater flows both into and out of the region, it is understandable that diversity within the capital region's localities will be greater.

For the majority of localities in the core regions, high rates of entrepreneurship are generally found in terms of both dynamic entrepreneurship - new entrepreneurial activity and static entrepreneurship - existing entrepreneurial activity. Given that entrepreneurial 
activity is negatively related to collective actions and, in the case of new entrepreneurship, more feminine and caring cultures, it can be suggested that more individualistic and 'masculine' cultures may promote entrepreneurial activities to a greater extent (McClelland 1961; Shane 1992). However, as previously noted, factors such as institutions, industrial structure and aggregate demand are likely to also partly explain differences in local entrepreneurship (Gould and Keeble 1984; Wennekers et al. 2007), and these variables are explored in the following analysis.

The simple ordinary least squares regressions of entrepreneurial activity on the community culture measures are reported in Tables 2 and 3, whereby the measures are treated as exogenous (the first stage regressions for formal institutions and cultural components respectively, are reported in Tables A5 and A6, but are not discussed here due to space constraints). The regressions appear to explain differences in new and existing entrepreneurial activity measures relatively well, accounting for over 80 per cent of the variance of both types of entrepreneurial activity. With the surprising exception of engagement with education and work, all cultural components are found to be significantly related to at least one form of entrepreneurial activity. A number of significant relationships between community culture and entrepreneurship are found. In particular, social cohesion, social rules and collective action are found to be negatively associated with new entrepreneurial activity. This is a clear signal that, once other relevant factors are controlled for, a number of dimensions of socio-spatial culture have a strong significant association with rates of dynamic entrepreneurship. In particular, the strong negative relationship found between social cohesion and new entrepreneurial activity potentially reflects the need to allow new ideas and ways of thinking to enter a locality to exploit the opportunities available (Florida 2002; Levie 2007). Also, although trust may be relatively high in more cohesive communities, it is possible that these strong bonding ties form a barrier to new information 
entering the locality. The negative relationship between collective action and existing entrepreneurial activity is also consistent with the predictions of studies such as Mueller and Thomas (2001). When using entrepreneurship measures scaled by the economically active population, the one key change is that the negative relationship between engagement with education and work and new entrepreneurship becomes significant.

\section{PLEASE INSERT TABLES 2 AND 3 ABOUT HERE}

In terms of existing entrepreneurial activity, the three significant relationships between new entrepreneurship and cultural components are reversed. The results instead suggest that localities with more cohesive, feminine and caring, social rule adhering communities have higher levels of static entrepreneurial activity. This is consistent with studies that have noted the importance of social capital in providing the trust required for business interactions to take place (Knack and Keefer 1997; Zak and Knack 2001; Beugelsdijk et al. 2004; Guiso et al. 2004; Westund and Bolton 2003; Westlund et al. 2014). The differences in results for new and existing entrepreneurship may highlight the importance in recognising that some cultural components may encourage new venture creation, but their survival and growth may be best fostered by other cultures. However, there is still evidence that a culture that legitimizes individualistic entrepreneurial activities plays a role, as collective activities and preferences for equality are negatively associated with existing entrepreneurship.

Beyond the community culture factors, population growth, which is suggestive of long term increasing aggregate demand, is positively associated with new entrepreneurship. There is also evidence that many new entrepreneurs were pushed into entrepreneurial activity by the weak economic conditions present in 2010. Change in the unemployment rate is positively associated with new entrepreneurship, whilst income growth shows a negative 
association. Industrial diversity appears to limit new venture creation. As found in other studies, such as Mueller (2006) and Lafuente et al. (2007), existing entrepreneurship is associated with increased levels of new entrepreneurship. The confidence that wellfunctioning institutions provide also appears to allow and encourage entrepreneurs to tolerate the risk of starting a new venture (Hwang and Powell 2005; Foreman-Peck and Zhou 2010). Thus, both the less formal institutions associated with a thriving SME sector and more formal institutions appear to play a role.

With regard to existing entrepreneurship, many of these relationships are again reversed, so that weaker demand conditions, as captured by rising unemployment, has a negative effect on existing entrepreneurship. This is consistent with studies suggesting that entrepreneurship may act as a refuge in weaker economies, but that such activities may be only temporary (Bradbury 1994). Population growth understandably has a negative effect on static measures of entrepreneurship, as net firm creation would be required to maintain existing entrepreneurship. Formal institutions are negatively associated with existing entrepreneurship, which may be due to such institutions providing greater alternative employment opportunities.

\section{PLEASE INSERT TABLE 4 ABOUT HERE}

In order to preserve space, the coefficients associated with all five cultural dimensions are reported in Table 4 with the other explanatory variables not shown being the same as those included in the models presented in Tables 2 and 3. Also, Table 5 provides an alternative set of results based on the key individual indicators within each cultural component, rather than the overall measure. The significant associations found between community culture and entrepreneurship in Tables 4 and 5 largely echo those found in Tables 2 and 3, but further 
suggest that some forms of community culture are highly interrelated to entrepreneurial activity. In this case, it becomes clear that high rates of existing entrepreneurial activity are often strongly associated with rates of new entrepreneurial activity. In other words, the results suggest a range of bidirectional relationships not only between both forms of entrepreneurship, but also between entrepreneurship and particular aspects of community culture, such as collective action in the form of the proportion of the population voting for left of centre parties. Also, the results indicate that certain components of community culture may develop due to the presence or otherwise of more formal institutions, with a relationship found for formal institutions and engagement with education and work, adherence to social rules and collective action. In the case of engagement with education and work, and adherence to social rules, formal institutions appear to complement these aspects of culture. However, in the case of collective action there is a negative relationship with the presence of strongly performing formal institutions, as may be expected if collective actions are compensating for institutional weaknesses (Durlauf and Fafchamps 2003).

\section{PLEASE INSERT TABLE 5 ABOUT HERE}

Some studies suggest that the development of certain aspects of culture are the result of the prevailing institutions (Rodríguez-Pose and Storper 2006), resulting in a degree of path dependency in the relationship, as argued by the emerging school of evolutionary economic geography (Boschma 2004; Stam 2010). This is confirmed for three of the five components of community culture examined here. More broadly, a growing stream of research is focusing on the role of institutions in shaping local and regional success or decline (Rafqui 2009; Gertler 2010; Storper 2010; Rodríguez-Pose 2013). Indeed, it may well be the case that 
institutional factors moderate the relationship between community culture and entrepreneurship at the local level (Blanchflower 2000; Freytag and Thurik 2007).

The final piece of analysis considers whether or not community culture itself acts as a moderator of the relationship between other drivers of entrepreneurial activity and the realized levels of entrepreneurial activity. We concentrate on new entrepreneurship and the moderating effect of culture on the impact of changes in unemployment rates. The change in unemployment is selected as it consistently has a significant positive influence on new entrepreneurship in the results above. Table 6 presents the results when an interaction term between change in unemployment and community culture is allowed to enter the new entrepreneurship regression. All other controls and instruments remain the same as in the previous calculations. Overall, the results suggest that community culture has more of a direct relationship with new entrepreneurship, rather than moderating the impact of unemployment for four of the cultural components. The one exception is engagement with education and work. A positive interaction term is found, suggesting that the push of unemployment into new entrepreneurship is even greater where a culture of self-sufficiency and long term planning is present.

\section{PLEASE INSERT TABLE 6 ABOUT HERE}

\section{Discussion and Conclusion}

This paper has examined the relationship between socio-spatial culture and entrepreneurship. From a theoretical perspective, the paper develops the notion of local community culture to conceptualize various dimensions of socio-spatial culture, integrating these with both static and dynamic notions of local entrepreneurship. Empirically, the paper develops a number of indices to represent the different dimensions of culture. Furthermore, through regression 
modelling, the associations between socio-spatial culture and entrepreneurship have been examined in detail, resulting in a range of significant relationships emerging. In particular, dimensions of socio-spatial culture relating to social cohesion, collective action and social rules are found to be significantly associated with levels of dynamic entrepreneurship within local economies.

Socio-spatial culture is also found to be associated with static entrepreneurship, but frequently in a converse manner to that found for dynamic entrepreneurship. This suggests that culture should be considered as having quite different influences on the number and nature of new entrepreneurs, compared to its impact on the nature and activities of entrepreneurial incumbents. However, the relationship between socio-spatial culture and entrepreneurship potentially contains bidirectional relationships with each reinforcing the other, which is likely to be due to both factors forming part of the wider socio-economic culture of a locality or region. It is also found that culture is influenced by the quality of formal institutions present, but the nature of this relationship can be of either a complementary or substitute nature depending on the component of culture examined.

Generally, localities in more entrepreneurial regions are found to display more individualistic, diverse and masculine cultures. However, the acceptance of social rules is also stronger, which may mean that localities in more entrepreneurially peripheral regions have adopted differing cultures to partly compensate for relatively poorly functioning formal institutions (Durlauf and Fafchamps 2003; Farole et al. 2011). Furthermore, institutions may direct individuals or organizations towards the adoption of similar practices and structures to those currently prevailing in a locality, ensuring they gain support and legitimacy for their actions (DiMaggio and Powell 1983; Etzioni 1987; Kibler et al. 2014).

In general, it is clear that the type of entrepreneurial activity present in a locality may be influenced by the quality of institutions present (Stenholm et al. 2013). Whilst notions of 
institutional entrepreneurship highlight the role of individuals in influencing institutional change (DiMaggio 1988), positive effects may be limited by pressures towards stasis, with key individuals in a locality looking to protect institutions that promote dominant activities in which they have a vested interest (Seo and Creed 2002; Battilana et al. 2009).

Along with the apparent association between culture and entrepreneurship, the interplay between the static and dynamic entrepreneurial facets of an economy will influence the extent to which potential future entrepreneurs are likely to remain within a particular locality or migrate elsewhere. Clearly, this influences the nature of policies that are most appropriate for encouraging entrepreneurial activities. For those places with strong rates of static entrepreneurship, rates of dynamic entrepreneurial activity are also likely to be relatively high, as well as being associated with a pro-entrepreneurial socio-spatial culture. For localities in more peripheral regions, a socio-spatial culture less attuned to high rates of entrepreneurship is likely to be coupled with a lack of long-term investment in skills and expertise. However, whilst these localities may lack relevant financial, physical and human capital, their strong rates of collective action suggests that a pooling of community resources may be one way to overcome the deficiencies they face, and development policy may be best focused upon seeing this apparent 'weakness' as a strength.

Overall, however, the findings indicate a significant challenge for policymaking in more peripheral localities and regions in terms of the extent to which they seek to evolve from socio-spatial cultures high in communal and collective values, to cultural values that could be considered more atomistic and individualistic, as typified by more entrepreneurial places. Policymakers first need to examine why a locality or region has particular traits, which in the case of many of the weakest entrepreneurial localities in the UK is clearly a legacy of post-industrialism. A mix of policies seeking to influence both socio-spatial culture and entrepreneurship are likely to be required to facilitate entrepreneurially-driven economic 
development, with the need for each form of intervention to be mutually compatible. Without such compatibility success is likely to be limited.

Given the level of interaction and transformation between the two phenomena of culture and entrepreneurship, which appear to be deeply interrelated, as well as the role of the economic cycle in mediating these relationships, entrepreneurial economic development policies appropriate for one locality are unlikely to be appropriate for another with a markedly different socio-spatial culture. Furthermore, the impact of any policy change is unlikely to be straightforward, as influences through changes in support mechanisms and formal institutions targeted at enhancing entrepreneurial activity may have as yet unknown impacts upon the underlying socio-spatial culture. Equally attempts to modify culture through, for example, educational programmes may have unknown ramifications that will impact not only on entrepreneurial activity, but the socio-economics of development as whole. This link between education and socio-spatial culture is one that has become a very sensitive political issue in the UK precisely in the area of social cohesion identified by this study (Pearson 2014).

Finally, there are a number of limitations to the present study which should be noted, most relating to the availability and consistency of data. Many of the measures used reflect activities associated with the underlying socio-spatial culture rather than directly capturing attitudes and beliefs. One effect of this use of more proxy measures could be that in some cases the influence of cultural factors is overestimated. The availability of consistent data over a longer period would allow the adoption of panel data approaches that would help to identify the strength of causal links in the bidirectional relationships, which the current analysis cannot determine. Furthermore, qualitative work would be invaluable in refining the appropriate and distinct cultural components most pertinent to entrepreneurial activity. Therefore, as more data becomes available it will be possible to explore cultural differences 
more directly, and more detailed datasets may also allow the examination of endogenous measures of culture, where more than one aspect of socio-spatial culture is considered at any one time, as well as the influence that socio-spatial culture has over different time periods.

\section{References}

Acs, Z. J., Desai, S., and Hessels, J. 2008. Entrepreneurship, economic development and institutions. Small Business Economics 31(3): 219-34.

Acs, Z. J., Braunerhjelm, P., Audretsch, D. B., and Carlsson, B. 2009. The knowledge spillover theory of entrepreneurship. Small Business Economics 32(1): 15-30.

Afonso, A., Schuknecht, L., and Tanzi, V. 2005. Public sector efficiency: an international comparison. Public Choice 123(3/4): 321-47.

Aghion, P., Alesina, A., and Trebbi, F. 2004. Endogenous political institutions. Quarterly Journal of Economics 119(2): 565-612.

Agnew, J. 1989. The devaluation of place in social science. In The Power of Place eds. J. Agnew and J. Duncan, 9-29. Boston: Unwin Hyman.

Anderson, A. R., and Smith, R. 2007. The moral space in entrepreneurship: an exploration of ethical imperatives and the moral legitimacy of being enterprising. Entrepreneurship and Regional Development 19(6): 479-97.

Andersson, M., and Koster, S. 2011. Sources of Persistence in Regional Start-up Rates: Evidence from Sweden. Journal of Economic Geography 11(1): 179-201.

Aoki, M. 2001. Toward a comparative institutional analysis. Cambridge, MA: MIT Press.

Aoyama, Y. 2009. Entrepreneurship and regional culture: the case of Hamamatsu and Kyoto, Japan. Regional Studies 43(3): 495-512.

Armington, C., and Acs, Z. J. 2002. The determinants of regional variation in new firm formation. Regional Studies 36(1): 33-45. 
Atkinson, R., and Kintrea, K. 2001. Disentangling area effects: evidence from deprived and non-deprived neighbourhoods. Urban Studies 38(12): 2277-98.

Audretsch, D., and Fritsch, M. 1994. The geography of firm births in Germany. Regional Studies 18(4): 359-65.

Audretsch, D., and Keilbach, M. 2004a. Entrepreneurship and regional growth: an evolutionary interpretation. Journal of Evolutionary Economics 14(5): 605-16.

Audretsch, D. B., and Keilbach, M. 2004b. Entrepreneurship capital and economic performance. Regional Studies 38(8): 949-59.

Audretsch, D., and Thurik, R. 2004. A model of entrepreneurial economy. International Journal of Entrepreneurship and Education 2(2): 143-66.

Autio, E., and Fu, K. 2015. Economic and political institutions and entry into formal and informal entrepreneurship. Asia-Pacific Journal of Management 32(1): 67-94.

Baker, K., Dalton, R., and Hildebrandt, K. 1981. Germany Transformed. Cambridge, MA: Harvard University Press.

Battilana, J., Leca, B., and Boxenbaum, E. 2009. How actors change institutions: towards a theory of institutional entrepreneurship. Academy of Management Annals 3(1): 65-107.

Baum, J. A. C., and Silverman, B. S. 2004. Picking winners or building them? Alliance, intellectual, and human capital as selection criteria in venture financing and performance of biotechnology startups. Journal of Business Venturing 17(4): 411-436.

Baum, J. R., Olian, J. D., Erez, M., Schnell, E. R., Smith, K. G., Sims, H. P., Scully, J. S., and Smith, K. A. 1993. Nationality and work role interactions: a cultural contrast of Israeli and U.S. entrepreneurs’ versus managers’ needs. Journal of Business Venturing 8(6): 499-512.

Baumol, W. J. 1990. Entrepreneurship: Productive, Unproductive, and Destructive. Journal of Political Economy 98(5 part 1): 893-921. 
Becker, S. O., and Woessmann, L. 2009. Was Weber Wrong? A Human Capital Theory of Protestant Economic History. Quarterly Journal of Economics 124(2): 531-96.

Bénabou, R., and Tirole, J. 2006. Belief in a just world and redistributive politics. Quarterly Journal of Economics 121(2): 699-746.

Bennett, R., and Dann, S. 2000. The changing experience of Australian female entrepreneurs. Gender, Work and Organization 7(2): 75-82.

Beugelsdijk, S. 2007. Entrepreneurial culture, regional innovativeness and economic growth. Journal of Evolutionary Economics 17(2): 187-210.

Beugelsdijk, S., De Groot, H., and Van Schaik, A. B. T. M. 2004. Trust and economic growth: a robustness analysis. Oxford Economic Papers 56(1): 118-34.

Beugelsdijk, S., and Maseland, R. 2011. Culture in economics: history, methodological reflections and contemporary applications. Cambridge: Cambridge University Press.

Blanchflower, D. G. 2000. Self-employment in OECD countries. Labour Economics 7(5): 471-505.

Blau, D. 1987. A time-series analysis of self-employment in the United States. Journal of Political Economy 95(3): 445-67.

Boettke, P. J., and Coyne, C. J. 2009. Context matters: Institutions and entrepreneurship. Foundations and Trends in Entrepreneurship 5(3): 135-209.

Boschma, R. A. 2004. Competitiveness of regions from an evolutionary perspective. Regional Studies 38(9): 1001-14.

Bosma, N., and Schutjens, V. 2009. Mapping entrepreneurial activity and entrepreneurial attitudes in European regions. International Journal of Entrepreneurship and Small Business 7(2): 191-213. 
Bosma, N., and Schutjens, V. 2011. Understanding regional variation in entrepreneurial activity and entrepreneurial attitude in Europe. Annals of Regional Science 47(3): 71142.

Bradbury, K. L. 1994. New England job changes during the recession: the role of selfemployment. New England Economic Review September/October: 45-57.

Braunerhjelm, P., and Henrekson, M. 2013. Entrepreneurship, institutions, and economic dynamism: lessons from a comparison of the United States and Sweden. Industrial and Corporate Change 22(1): 107-30.

Brennan, A., Rhodes, J., and Tyler, P. 2000. The nature of local area social exclusion in England and the role of the labour market. Oxford Review of Economic Policy 16(1): 129-46.

Bruni, A., Gherardi, S., and Poggio, B. 2004. Doing gender, doing entrepreneurship: an ethnographic account of intertwined practices. Gender, Work and Organization 11(4): 407-29.

Bruton, G., and Ahlstrom, D. 2003. An institutional view of China's venture capital industry: explaining the differences between China and the west. Journal of Business Venturing 18(2): 233-59.

Carree, M. A., Van Stel, A. J., Thurik, A. R., and Wennekers, S. 2002. Economic development and business ownership: an analysis using data of 23 OECD countries in the period 1976-1996. Small Business Economics 19(3): 271-90.

Carter, S., Marlow, S., and Bennett, D. 2012. Gender and entrepreneurship. In Enterprise and Small Business: Principles, Practice and Policy. eds. S. Carter and D. Jones-Evans, 21831. London: Pearson. 
Charron, N., Lapuente, V., and Rothstein, B. 2011. Measuring Quality of Government and Sub-National Variation. Brussels: European Commission Directorate-General Regional Policy Directorate Policy Development.

Charron, N., Dijkstra, L., and Lapuente, V. 2014. Regional governance matters: quality of Government within European Union member states. Regional Studies 48(1): 68-90.

Casson, M. 1982. The entrepreneur: an economic theory. Oxford: Martin Robertson.

Casson, M. 1995. Entrepreneurship and Business Culture: Studies in the Economics of Trust, Volume 1. Aldershot: Edward Elgar.

Casson, M., and Della Giusta, M. 2007. Entrepreneurship and social capital: analysing the impact of social networks on entrepreneurial activity from a rational action perspective. International Small Business Journal 25(3): 220-44.

Chell, E., Haworth, J., and Brearley, S. 1991. The entrepreneurial personality: concepts, cases and categories. London: Routledge.

Daly, G. G. 1998. Entrepreneurship and business culture in Japan and the U.S.. Japan and the World Economy 10(4): 487-94.

Davidsson, P. 1995. Culture, structure and regional levels of entrepreneurship. Entrepreneurship and Regional Development 7(1): 41-62.

Davidsson, P., and Honig, B. 2003. The role of social and human capital among nascent entrepreneurs. Journal of Business Venturing 18(3): 301-31.

Davidsson, P., and Wiklund, J. 1997. Values, beliefs and regional variations in new firm formation rates. Journal of Economic Psychology 18(2/3): 179-99.

Denzau, A. T., and North, D. C. 1994. Shared mental models: ideologies and institutions. Kyklos 47(1): 3-31.

DiMaggio, P. J. 1988. Interest and agency in institutional theory. In Institutional Patterns and Organisations. ed. L. Zucker, 3-22. Cambridge, MA: Ballinger. 
DiMaggio, P. J., and Powell, W. W. 1983. The iron cage revisited: institutional isomorphism and collective rationality in organizational fields. American Sociological Review 48(2): 147-60.

Durand, J. D. 1975. The Labor Force in Economic Development: A Comparison of International Census Data, 1946-1996. Princeton, NJ: Princeton University Press.

Durkheim, E. 1893. The Division of Labour in Society. New York, NY: Macmillan.

Durlauf, S. N., and Fafchamps, M. 2003. Empirical studies of social capital: a critical survey. Wisconsin Madison - Social Systems Working Paper Series, WP2003-12. Madison, WI: Social Systems Research Institute, University of Wisconsin-Madison.

Easterlin, R. A. 1974. Does economic growth improve the human lot? Some empirical evidence. In Nations and Households in Economic Growth. eds. P. A. David and M. W. Reder. 89-125. New York, NY: Academic Press.

Easterly, W., and Levine, R. 1997. Africa's growth tragedy: politics and ethnic divisions. Quarterly Journal of Economics 112(4): 1203-50.

El Harbi, S., and Anderson, A. R. 2010. Institutions and the shaping of different forms of entrepreneurship. Journal of Socio-Economics 39(3): 436-44.

Elfenbein, D. W., Hamilton, B. H., and Zenger, T. R. 2010. The Small Firm Effect and the Entrepreneurial Spawning of Scientists and Engineers. Management Science 56(4): 659681.

Ettlinger, N. 2003. Cultural economic geography and a relational and microspace approach to trusts, rationalities, networks, and change in collaborative workplaces. Journal of Economic Geography 3(2): 1-28.

Etzioni, A. 1987. Entrepreneurship, adaptation and legitimation: a macro-behavior perspective. Journal of Economic Behavior and Organization 8(2): 175-89. 
Evans, D. S., and Leighton, L. S. 1989. Some empirical aspects of entrepreneurship. American Economic Review 79(3): 519-35.

Farole, T., Rodríguez-Pose, A., and Storper, M. 2011. Human geography and the institutions that underlie economic growth. Progress in Human Geography 35(1): 58-80.

Fayolle, A., Basso, O., and Bouchard. V. 2010. Three levels of culture and firms' entrepreneurial orientation: a research agenda. Entrepreneurship and Regional Development 22(7/8): 707-30.

Florida, R. 2002. The Rise of the Creative Class. New York, NY: Basic Books.

Foreman-Peck, J. and, Zhou, P. 2010. Entrepreneurial culture or institutions? A twentiethcentury resolution. In The determinants of entrepreneurship: leadership, culture, institutions. eds. J. L. García-Ruiz and P. A. Toninelli, 125-42. London: Pickering and Chatto.

Foreman-Peck, J., and Zhou, P. 2013. The strength and persistence of entrepreneurial cultures. Journal of Evolutionary Economics 23(1): 163-87.

Fornahl, D. 2003. Entrepreneurial activities in a regional context. In Cooperation, Networks, and Institutions in Regional Innovation Systems. eds. D. Fornahl and T. Brenner, 38-57., Cheltenham: Edward Elgar.

Fotopoulos, G. 2014. On the spatial stickiness of UK new firm formation rates. Journal of Economic Geography 14(3): 651-79.

Frederking, L. C. 2002. Is there an endogenous relationship between culture and economic development? Journal of Economic Behavior and Organization 48(2): 105-26.

Freytag, A., and Thurik, R. 2007. Entrepreneurship and its determinants in a cross country setting. Journal of Evolutionary Economics 17(2): 117-31.

Fritsch, M., and Mueller, P. 2005. How persistent are regional start-up rates? An empirical analysis. Research of Technological Innovation and Management Policy 9: 71-82. 
Fritsch, M., and Wyrwich, M. 2014a. The Long Persistence of Regional Levels of Entrepreneurship: Germany, 1925-2005. Regional Studies 48(6): 955-73.

Fritsch, M., and Wyrwich, M. 2014b. The effect of regional entrepreneurship culture on economic development: Evidence for Germany. Jena Economic Research Papers, No. 2014-014. Jena: Friedrich Schiller University and Max Planck Institute of Economics.

Furman, J. L., Porter, M. E., and Stern, S. 2002. The determinants of national innovative capacity. Research Policy 31(6): 899-933.

George, G., and Prabhu, G. 2000. Developmental financial institutions as catalysts of entrepreneurship in emerging economies. Academy of Management Review 25(3): 62030.

Gerson, K. C., Stueve, A., and Fischer, C. 1977. Attachment to place. In Networks and Places: Social Relations in the Urban Setting. ed. C. Fischer, 139-61. New York, NY: Free Press.

Gertler, M. 2010. Rules of the game: The place of institutions in regional economic change. Regional Studies 44(1): 1-15.

Greene, W. H. 2003. Econometric Analysis. Upper Saddle River, NJ: Prentice Hall.

Gould, A., and Keeble, D. 1984. New firms and rural industrialization in East Anglia. Regional Studies 18(3): 189-201.

Gregson, N., Simonsen, K., and Vaiou, D. 1999. The meaning of work: some arguments for the importance of culture within formulations of work in Europe. European Urban and Regional Studies 6(3): 197-214.

Greif, A. 1993. Contract enforceability and economic institutions in early trade: the Maghribi traders’ coalition. American Economic Review 83(3): 525-48. 
Greif, A. 1994. Cultural beliefs and the organization of society: a historical and theoretical reflection on collectivist and individualist societies. Journal of Political Economy 102(5): 912-50.

Gross, A. C., Holtzblatt, M., Javalgi, R., Poor, J., and Solymossy, E. 2013. Professional occupations, knowledge-driven firms, and entrepreneurship: a national and regional analysis. Business Economics 48(4): 246-59.

Guesnier, B. 1994. Regional variations in new firm formation in France. Regional Studies 28(4): 347-58.

Guiso, L., Sapienza, P., and Zingales, L. 2004. The role of social capital in financial development. American Economic Review 94(3): 526-56.

Hall, P. A., and Soskice, D. 2001. An introduction to varieties of capitalism. In Varieties of Capitalism: The Institutional Foundations of Comparative Advantage. eds. P. A. Hall and D. Soskice, 1-68. Oxford: Oxford University Press.

Harding, R. 2007. GEM UK 2006. London: London Business School.

Hart, M., and Gudgin, G. 1994. Spatial variations in new firm formation in the Republic of Ireland, 1980-1990. Regional Studies 28(4): 367-80.

Hayton, J. C., George, G., and Zahra, S. A. 2002. National culture and entrepreneurship: a review of behavioural research. Entrepreneurship Theory and Practice 26(4): 33-55.

Hechavarria, D. M., and Reynolds, P. D. 2009. Cultural norms and business start-ups: the impact of national values on opportunity and necessity entrepreneurs. International Entrepreneurship and Management Journal 5(4): 417-37.

Helliwell, J., and Putnam, R. 1995. Economic growth and social capital in Italy. Eastern Economic Journal 21(3): 295-307.

Henrekson, M., and Sanandaji, T. 2011. The interaction of entrepreneurship and institutions. Journal of Institutional Economics. 7(01): 47-75. 
Heydemann, S. 2008. Institutions and economic performance: the use and abuse of culture in new institutional economics. Studies in Comparative and International Development, 43(1): 27-52.

Hirsch, F. 1977. Social Limits to Growth. London: Routledge and Kegan Paul.

Hirschman, A. O. 1965. Obstacles to development: a classification and a quasi-vanishing act. Economic Development and Cultural Change 13(4): 385-93.

Hoffman, K., Parejo, M., Bessant, J., and Perren, L. 1998. Small firms, R\&D, technology and innovation in the UK: a literature review. Technovation 18(1): 39-55.

Hofstede, G. 1980. Culture's consequences: Internal differences in work related values. Beverly Hills, CA: Sage.

Hofstede, G. 2001. Culture’s Consequences: Comparing Values, Behaviors, Institutions, and Organizations Across Nations, Second Edition. Thousand Oaks, CA: Sage.

Hofstede, G., Noorderhaven, N. G., Thurik, A. R., Uhlaner, L. M., Wennekers, A. R. M., and Wilderman, R. E. 2004. Culture's role in entrepreneurship: self-employment out of dissatisfaction. In Innovation, entrepreneurship and culture: the interaction between technology, progress and economic growth. eds. T. E. Brown and J. Ulijn, 162-203. Cheltenham: Edward Elgar.

Huggins, R., and Izushi, H. 2007. Competing for Knowledge: Creating, connecting and growing. London: Routledge.

Huggins, R., and Thompson, P. 2015. Culture and place-based development: a socioeconomic analysis. Regional Studies 49(1): 130-59.

Huggins, R., and Williams, N. 2011. Entrepreneurship and regional competitiveness: The role and progression of policy. Entrepreneurship and Regional Development 23(9-10): 90732. 
Hundley, G. 2001. What and when are the self-employed more satisfied with their work, Industrial Relations 40(2): 293-316.

Hwang, H., and Powell, W. W. 2005. Institutions and entrepreneurship. In Handbook of Entrepreneurship Research: Interdisciplinary Perspectives. eds. S. A. Alvarez, R. Agarwal and O. Sorenson, 201-32. New York, NY: Springer.

Jack, S. L., and Anderson, A. R. 2002. The effects of embeddedness on the entrepreneurial process. Journal of Business Venturing 17(5): 467-87.

Jones, E. L. 2006. Cultures merging: a historical and economic critique of culture. Princeton, NJ: Princeton University Press.

Johnstone, H., and Lionais, D. 2004. Depleted communities and community business entrepreneurship: revaluing space through place. Entrepreneurship and Regional Development 16(3): 217-33.

Kaiser, H. F. 1960. The application of electronic computers to factor analysis. Educational and Psychological Measurement 20(1): 141-51.

Kaufmann, D., Kraay, A., and Mastruzzi, M. 2009. Governance Matters VIII: Aggregate and Individual Governance Indicators for 1996-2008. World Bank Policy Research Paper, \#4978. Washington, DC: World Bank.

Kearns, A., and Forrest, R. 2000. Social cohesion and multilevel urban governance. Urban Studies 37(5/6): 995-1017.

Kemeny, T. 2014. Immigrant diversity and economic performance in cities. International Regional Science Review DOI: 0160017614541695.

Kibler, E., Kautonen, T., and Fink, M. 2014. Regional social legitimacy of entrepreneurship: implications for entrepreneurial intention and start-up behaviour. Regional Studies 48(6): 995-1015. 
Kim, G. 2007. The analysis of self-employment levels over the life-cycle. Quarterly Review of Economics and Finance 47(3): 397-410.

Knack, S., and Keefer, P. 1995. Institutions and economic performance: cross country tests using alternative institutional measures. Economics and Politics 7(3): 207-27.

Knack, S., and Keefer, P. 1997. Does social capital have an economic payoff? A crosscountry investigation. Quarterly Journal of Economics 112(4): 1251-88.

Kwong, C., and Thompson, P. 2015. The when and why: student entrepreneurial aspirations. Journal of Small Business Management DOI: 10.1111/jsbm.12146.

Lafuente, E., Vaillant, Y., and Rialp, J. 2007. Regional differences in the influence of role models: Comparing the entrepreneurial process of rural Catalonia. Regional Studies 41(6): 779-96.

Lal, D. 1998. Unintended consequences: the impact of factor endowments, culture, and politics on long run economic performance. Cambridge, MA: MIT Press.

Landes, D. S. 1953. Social attitudes, entrepreneurship and economic development: A comment. Explorations in Entrepreneurial History 6: 245-72.

Lang, R., and Roessl, D. 2011. The role of social capital in the development of communitybased co-operatives. In New Developments in the Theory of Networks: Franchising, Alliances and Cooperatives. eds. M. Tuunanen, J. Windsperger, G. Cliquet and G. Hendrikse, 353-370. Berlin Heidelberg: Springer-Verlag.

Langevang, T., Gough, K. V., Yankson, P. W., Owusu, G., and Osei, R. 2015. Bounded entrepreneurial vitality: The mixed embeddedness of female entrepreneurship. Economic Geography 91(4): 449-73.

Lee, N. 2011. Ethnic diversity and employment growth in English cities. Urban Studies 48(2): 407-25. 
Lee, N. 2015. Migrant and ethnic diversity, cities and innovation: Firm effects or city effects? Journal of Economic Geography 15(4): 769-96.

Lee, S. Y., Florida, R., and Acs, Z. J. 2004. Creativity and entrepreneurship: a regional analysis of new firm formation. Regional Studies 38(8): 879-91.

Lévesque, M., and Minniti, M. 2006. The effect of aging on entrepreneurial behavior. Journal of Business Venturing 21(2): 177-94.

Levie, J. 2007. Immigration, in-migration, ethnicity and entrepreneurship in the United Kingdom. Small Business Economics 28(2/3): 143-69.

Levie, J. D., and Hunt, S. 2005. Culture, institutions and new business activity: evidence from the global entrepreneurship monitor. In. Frontiers of Entrepreneurship Research 2004: proceedings of the twenty-fourth annual entrepreneurship research conference. eds. S. A. Zahra, C. G. Brush, P. G. Greene, G. D. Meyer, P. Davidsson, R. T. Harrison, J. Sohl, J. Fiet, M. Lerner, A. Zacharakis, and C. Mason, 519-33. Babson Park: Babson College.

Licht, A. N., Goldschmidt, C., and Schwartz, S. H. 2007. Cultural rules: the foundations of the rule of law and other norms of governance. Journal of Comparative Economics 35(4): 659-88.

Lorenzen, M. 2007. Social capital and localised learning: proximity and place in technological and institutional dynamics. Urban Studies 44(4): 799-817.

Malecki, E. J. 2009. Geographical environments for entrepreneurship. International Journal of Entrepreneurship and Small Business 7(2): 175-90.

Mauro, P. 1995. Corruption and growth. Quarterly Journal of Economics 110(3): 681-712.

Mauss, M. 1990/[1925]. The Gift: The Form and Reason for Exchange in Archaic Societies. trans. W. D. Halls. New York and London: WW Norton.

McClelland, D. C. 1961. The achieving society. Princeton, NJ: Van Nostrand. 
McGrath, R. G., Macmillan, I. C., Yang, E. A., and Tsai, W. 1992. Does culture endure, or is it malleable? Issues for entrepreneurial economic development. Journal of Business Venturing 7(6): 441-58.

Miller, B. 1992. Collective action and rational choice: place, community, and the limits to individual self-interest. Economic Geography 68(1): 22-42.

Minniti, M. 2003. Entrepreneurship studies: a stocktaking. In Austrian Economics and Entrepreneurial Studies (Advances in Austrian Economics, Volume 6). eds. R. Koppl, J. Birner and P. Kurrild-Klitgaard, 9-37. Bingley: Emerald.

Mo, P. H. 2001. Corruption and economic growth. Journal of Comparative Economics 29(1): 66-79.

Mueller, P. 2006. Entrepreneurship in the region: breeding ground for nascent entrepreneurs. Small Business Economics 27(1): 41-58.

Mueller, P., Van Stel, A., and Storey, D. J. 2008. The effects of new firm formation on regional development over time: the case of Great Britain. Small Business Economics 30(1): 59-71.

Mueller, S. L., and Thomas, A. S. 2001. Culture and entrepreneurial potential: a nine country study of locus of control and innovativeness. Journal of Business Venturing 16(1): 51-75.

Nathan, M., and Lee, N. 2013. Cultural Diversity, Innovation, and Entrepreneurship: Firm-level Evidence from London. Economic Geography 89(4): 367-94.

Nelson, R. 1993. National innovation systems: a comparative analysis. New York, NY: Oxford University Press.

Nijkamp, P. 2003. Entrepreneurship in a modern network economy. Regional Studies 37(4): 395-405. 
Noorderhaven, N., Thurik, R., Wennekers, S., and Van Stel, A. 2004. The role of dissatisfaction and per capita income in explaining self-employment across 15 European countries. Entrepreneurship Theory and Practice 28(5): 447-66.

North, D. C. 1990. Institutions, institutional change and economic performance. Cambridge: Cambridge University Press.

North, D. C. 2005. Understanding the process of economic change. Princeton, NJ: Princeton University Press.

Obschonka, M., Andersson, H., Silbereisen, R. K., and Sverke, M. 2013. Rule-breaking, crime, and entrepreneurship: a replication and extension study with 37-year longitudinal data. Journal of Vocational Behavior 83(3): 386-96.

O’Farrell, P. N., and Crouchley, R. 1984. An industrial and spatial analysis of new firm formation in Ireland. Regional Studies 18(3): 221-36.

Ottaviano, G. I., and Peri, G. 2006. The economic value of cultural diversity: evidence from US cities. Journal of Economic Geography 6(1): 9-44.

Parasuraman, S., Purohit, Y. S., Godshalk, V. M., and Beutell, N. J. 1996. Work and family variables, entrepreneurial career success, and psychological well-being. Journal of Vocational Behavior 48(3): 275-300.

Pearson, A. 2014. Trojan Horse debate: We were wrong, all cultures are not equal, The $\begin{array}{llll}\text { Telegraph, } & \text { online, } & \text { retrieved } & 16\end{array}$ http://www.telegraph.co.uk/education/educationnews/10892606/Trojan-Horse-debate$\underline{\text { We-were-wrong-all-cultures-are-not-equal.html }}$

Pinillos, M.-J., and Reyes, L. 2011. Relationship between individualist-collectivist culture and entrepreneurial activity: evidence from Global Entrepreneurship Monitor data. Small Business Economics 37(1): 23-37. 
Portes, A., and Landolt, P. 2000. Social capital: promise and pitfalls of its role in development. Journal of Latin American Studies 32(2): 529-47.

Qian, H., Acs, Z. J., and Stough, R. R. 2013. Regional systems of entrepreneurship: the nexus of human capital, knowledge and new firm formation. Journal of Economic Geography 13(4): 559-87.

Rafiqui, P. S. 2009. Evolving economic landscapes: Why new institutional economics matters for economic geography. Journal of Economic Geography 9(3): 329-53.

Reynolds, P., Storey, D. J., and Westhead, P. 1994. Cross-national comparisons of the variation in new firm formation rates. Regional Studies 28(4): 443-56.

Rocha, H. O. 2013. Entrepreneurship and Regional Development: The Role of Clusters. Basingstoke: Palgrave Macmillan.

Rodrik, D. 2000. Institutions for high-quality growth: what they are and how to acquire them. Studies in Comparative International Development 35(3): 3-31.

Rodríguez-Pose, A. 2013. Do institutions matter for regional development? Regional Studies 47(7): 1034-47.

Rodríguez-Pose, A., and Storper, M. 2006. Better rules or stronger communities? On the social foundations of institutional change and its economic effects. Economic Geography 82(1): 1-25.

Rodríguez-Pose, A., and Di Cataldo, M. 2015. Quality of government and innovative performance in the regions of Europe. Journal of Economic Geography 15(4): 673-706.

Rodríguez-Pose, A., and Hardy, D. 2015. Cultural diversity and entrepreneurship in England and Wales. Environment and Planning A 47(2): 392-411.

Roland, G. 2004. Understanding institutional change: fast-moving and slow-moving institutions. Studies in Comparative International Development 38(4): 109-31. 
Santarelli, E., Carree, M., and Verheul, I. 2009. Unemployment and firm entry and exit: an update on a controversial relationship. Regional Studies 43(8): 1061-73.

Saxenian, A. 2006. The New Argonauts: Regional Advantage in a Global Economy. Cambridge, MA: Harvard University Press.

Schuman, H., and Scott, J. 1989. Generations and collective memories. American Sociological Review 54(3): 359-81.

Schumpeter, J. 1934. The theory of economic development. Cambridge, MA: Harvard University Press.

Seo, M-G., and Creed, W. E. D. 2002. Institutional contradictions, praxis, and institutional change: a dialectical perspective. Academy of Management Review 27(2): 222-47.

Shane, S. A. 1992. Why do some societies invent more than others? Journal of Business Venturing 7(1): 29-46.

Shane, S. 1993. Cultural influences on national rates of innovation. Journal of Business Venturing 8(1): 59-73.

Shane, S., and Cable, D. 2002. Network ties, reputation, and the financing of new ventures. Management Science 48(3): 364-81.

Shapero, A., and Sokol, I. 1982. The social dimensions of entrepreneurship. In Encyclopedia of Entrepreneurship. eds. C. A. Kent, D. I. Sexton and K. H. Vesper, 72-88. Englwood Cliffs: Prentice-Hall.

Shneor, R., Metin Camgöz, S., and Bayhan Karapinar, P. 2013. The interaction between culture and sex in the formation of entrepreneurial intentions. Entrepreneurship and Regional Development 25(9-10): 781-803.

Slack, J. 2005. The New Entrepreneur Scholarships: self-employment as a means to tackle social deprivation. Education and Training 47(6): 447-55 
Smith, D. M. 1999. Geography, community, and morality. Environment and Planning A 31(1): 19-35.

Spigel, B. 2013. Bourdieuian approaches to the geography of entrepreneurial cultures. Entrepreneurship and Regional Development 25(9-10): 804-18.

Stam, E. 2010. Entrepreneurship, Evolution and Geography. In The Handbook of Evolutionary Economic Geography. eds. R. Boschma and R. Martin, 139-61. Cheltenham: Edward Elgar.

Stam, K., Verbakel, E., and de Graaf, P. M. 2014. Do values matter? The impact of work ethic and traditional gender role values on female labour market supply. Social Indicators Research 116(2): 593-610.

Stenholm, P., Acs, Z. J., and Wuebker, R. 2013. Exploring country-level institutional arrangements on the rate and type of entrepreneurial activity. Journal of Business Venturing 28(1): 176-93.

Sternberg, R. 2009. Regional dimensions of entrepreneurship. Foundations and Trends in Entrepreneurship 5: 211-340.

Storey, D. J., and Johnson, S. 1987. Regional variations in entrepreneurship in the UK. Scottish Journal of Political Economy 34(3): 161-73.

Storper, M. 2008. Community and economics. In Community, Economic Creativity and Organization. ed. A. Amin and J. Roberts, 37-68. Oxford: Oxford University Press.

Storper, M. 2010. Why does a city grow? Specialisation, human capital or institutions? Urban Studies 47(10): 2027-50.

Tabachnick, B. G., and Fidell, L. S. 2007. Using multivariate statistics: 5th edition. Boston: Allyn and Bacon.

Tabellini, G. 2010. Culture and Institutions: Economic Development in the Regions of Europe. Journal of the European Economic Association 8(4): 677-716. 
Theil, H. 1972. Statistical Decomposition Analysis: With Applications in the Social and Administrative Sciences. Amsterdam: North Holland.

Thomas, A. S., and Mueller, S. L. 2000. A case for comparative entrepreneurship: assessing the relevance of culture. Journal of International Business Studies 31(2): 287-301.

Thomas, B. C., Williams, R., Thompson, P., and Packham, G. 2013. Use of the Internet and SME characteristics to expand scale and geographic scope of sales: the case of the United Kingdom. International Journal of Technology Diffusion 4(3): 1-37.

Thornton, P. H. 1999. The sociology of entrepreneurship. Annual Review of Sociology 25: 1946.

Thornton, P. H., and Flynn, K. H. 2003. Entrepreneurship, networks, and geographies In Handbook of Entrepreneurship Research. eds. Z. J. Acs and D. B. Audretsch, 401-433. New York, NY: Kluwer.

Thornton, P. H., Ribeiro-Soriano, D., and Urbano, D. 2011. Socio-cultural factors and entrepreneurial activity: an overview. International Small Business Journal 29(2): 10518.

Thurik, A. R., Carree, M. A., van Stel, A., and Audretsch, D. B. 2008. Does self-employment reduce unemployment? Journal of Business Venturing 23(6): 673-86.

Tran, T. B., Grafton, R. Q., and Kompas, T. 2009. Institutions matter: the case of Vietnam. Journal of Socio-Economics 38(1): 1-12.

Trettin, L., and Welter, F. 2011. Challenges for spatially oriented entrepreneurship research. Entrepreneurship and Regional Development 23(7-8): 575-602.

Trigilia, C. 1992. Italian industrial districts: neither myth nor interlude. In Industrial Districts and Local Economic Regeneration. eds. F. Pyke and W. Sengenberger, 33-47. Geneva: ILO.

Tylor, E. B. 1871. Primitive Culture, Vol 2. New York, NY: Brentano’s. 
Uhlaner, L., and Thurik, R. 2007. Postmaterialism influencing total entrepreneurial activity across nations. Journal of Evolutionary Economics 17(2): 161-85.

Vaillant, Y., and Lafuente, E. 2007. Do different institutional frameworks condition the influence of local fear of failure and entrepreneurial examples over entrepreneurial activity? Entrepreneurship and Regional Development 19(4): 313-37.

Van Maanen, J., and Schein, E. H. 1979. Toward a theory of organizational socialization. Research In Organizational Behavior 1(1): 209-64.

Verheul, I., Wennekers, S., Audretsch, D. B., and Thurik, R. A. 2001. An Eclectic Theory of Entrepreneurship. Tinbergen Institute Discussion Paper, TI 2001-030/3. Amsterdam/ Rotterdam: Tinbergen Institute for Economic Research.

Wagner, J., and Sternberg, R. 2004. Start-up activities, individual characteristics, and the regional milieu: lessons for entrepreneurship support policies from German micro data. Annals of Regional Science 38(2): 219-240.

Weber, M. 1930. The Protestant Ethic and the Spirit of Capitalism. London: Routledge.

Wennberg, K., Pathak, S., and Autio, E. 2013. How culture moulds the effects of selfefficacy and fear of failure on entrepreneurship. Entrepreneurship and Regional Development 25(9-10): 756-80.

Wennekers, S., Thurik, R., Van Stel, A., and Noorderhaven, N. 2007. Uncertainty avoidance and the rate of business ownership across 21 OECD countries, 1976-2004. Journal of Evolutionary Economics 17(2): 133-60.

Westlund, H., and Bolton, R. 2003. Local social capital and entrepreneurship. Small Business Economics 21(2): 77-113.

Westlund, H., Larsson, J. P., and Olsson, A. R. 2014. Start-ups and Local Entrepreneurial Social Capital in the Municipalities of Sweden. Regional studies 48(6): 974-94. 
Whittington, R. C. 1984. Regional bias in new formation in the UK. Regional Studies 18(3): 253-56.

Williamson, O. E. 2000. The new institutional economics: taking stock, looking ahead. Journal of Economic Literature 38(3): 595-613.

Wyrwich, M. 2012. Regional entrepreneurial heritage in a socialist and a post-socialist economy. Economic Geography 88(4): 423-45.

Wyrwich, M. 2015. Entrepreneurship and the intergenerational transmission of values. Small Business Economics 45(1): 191-213.

Zak, P., and Knack, S. 2001. Trust and growth. Economic Journal 111(470): 295-321.

Zellner, A., and Theil, H. 1962. Three stage least squares: simultaneous estimation of simultaneous equations. Econometrica 30(1): 54-78.

Zhang, Z., and Avery, R. D. 2009. Rule breaking in adolescence and entrepreneurial status: an empirical investigation. Journal of Business Venturing 25(5): 436-47. 
Figure 1: Entrepreneurship and Community Culture, Localities in Great Britain 2010

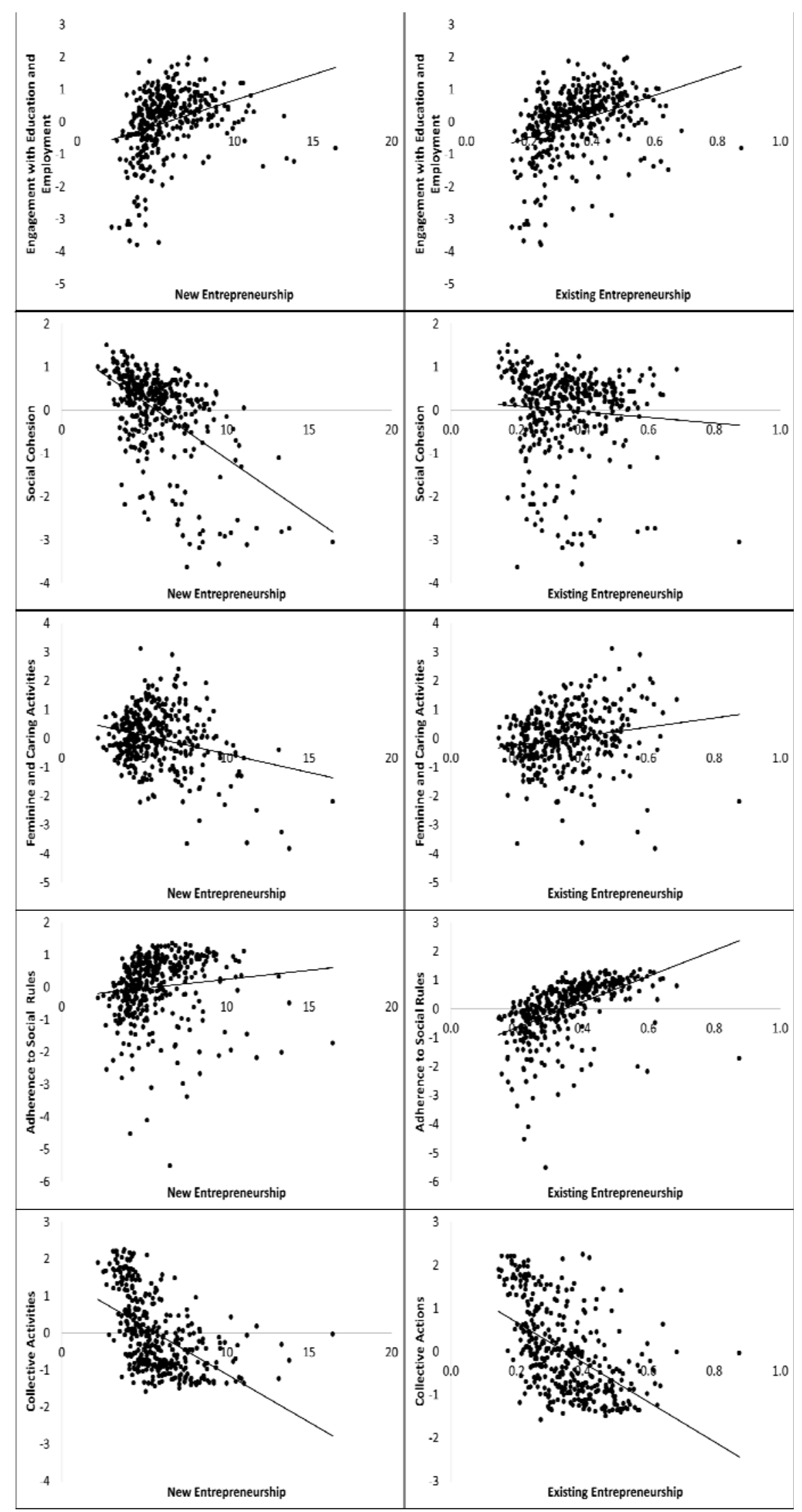



Table 1: Dimensions, Measures and Data Sources Utilized by the Analysis

\begin{tabular}{|c|c|c|c|}
\hline Dimension & Construct & Measure & Source \\
\hline \multirow{4}{*}{ Community Culture } & $\begin{array}{l}\text { Engagement with } \\
\text { Education and Work }\end{array}$ & Male economic activity rates & Annual Population Survey (APS) \\
\hline & $\begin{array}{l}\text { Engagement with } \\
\text { Education and Work }\end{array}$ & $\begin{array}{l}\text { Proportion of population with no formal } \\
\text { education }\end{array}$ & Annual Population Survey (APS) \\
\hline & $\begin{array}{l}\text { Engagement with } \\
\text { Education and Work }\end{array}$ & $\begin{array}{l}\text { Primary school absenteeism, proportion of } \\
\text { half day sessions }\end{array}$ & Schools Statistics \\
\hline & $\begin{array}{l}\text { Engagement with } \\
\text { Education and Work }\end{array}$ & $\begin{array}{l}\text { Secondary school absenteeism, proportion } \\
\text { of half day sessions }\end{array}$ & Schools Statistics \\
\hline \multirow{5}{*}{ Community Culture } & Social Cohesion & Ethnic similarity & Census \\
\hline & Social Cohesion & Religious similarity & Census \\
\hline & Social Cohesion & $\begin{array}{l}\text { Gross migration as a proportion of the } \\
\text { population }\end{array}$ & $\begin{array}{l}\text { National Health Service Central } \\
\text { Register }\end{array}$ \\
\hline & Social Cohesion & $\begin{array}{l}\text { Proportion of the population which is UK } \\
\text { born }\end{array}$ & Annual Population Survey \\
\hline & Social Cohesion & $\begin{array}{l}\text { Proportion of the population perceiving } \\
\text { themselves nationality of resident country }\end{array}$ & Annual Population Survey \\
\hline
\end{tabular}


Table 1: continued

\begin{tabular}{|c|c|c|c|}
\hline Dimension & Construct & Measure & Source \\
\hline \multirow{3}{*}{ Community Culture } & $\begin{array}{l}\text { Femininity and caring } \\
\text { attitudes }\end{array}$ & Female economic activity & Annual Population Survey \\
\hline & $\begin{array}{l}\text { Femininity and caring } \\
\text { attitudes }\end{array}$ & Female part-time employment & Annual Population Survey \\
\hline & $\begin{array}{l}\text { Femininity and caring } \\
\text { attitudes }\end{array}$ & $\begin{array}{l}\text { Unpaid care provision of } 1 \text { hour or more a } \\
\text { week }\end{array}$ & Census \\
\hline \multirow{4}{*}{ Community Culture } & Adherence to Social Rules & $\begin{array}{l}\text { Age standardized alcohol related deaths per } \\
100,000 \text { population }\end{array}$ & Health Statistics Quarterly \\
\hline & Adherence to Social Rules & Underage conceptions per 1000 women & Health Statistics Quarterly \\
\hline & Adherence to Social Rules & $\begin{array}{l}\text { Non-sexual violent crimes per } 1000 \\
\text { population }\end{array}$ & $\begin{array}{l}\text { Notifiable Crimes Recorded by } \\
\text { the Police }\end{array}$ \\
\hline & Adherence to Social Rules & Crimes by deception per 1000 population & $\begin{array}{l}\text { Notifiable Crimes Recorded by } \\
\text { the Police }\end{array}$ \\
\hline \multirow[b]{2}{*}{ Community Culture } & Collective Action & Trade union membership & Annual Population Survey \\
\hline & Collective Action & $\begin{array}{l}\text { Proportion of the population voting for left } \\
\text { of centre parties }\end{array}$ & Electoral Commission \\
\hline
\end{tabular}


Table 1: continued

\begin{tabular}{|c|c|c|c|}
\hline Dimension & Construct & Measure & Source \\
\hline $\begin{array}{l}\text { Existing Entrepreneurial } \\
\text { Activity }\end{array}$ & $\begin{array}{l}\text { Existing Entrepreneurial } \\
\text { Activity }\end{array}$ & $\begin{array}{l}\text { Small and Medium Sized Enterprises per } \\
\text { working age population (less than } 250 \\
\text { employees) }\end{array}$ & Business Demographics \\
\hline $\begin{array}{l}\text { New Entrepreneurial } \\
\text { Activity }\end{array}$ & $\begin{array}{l}\text { New Entrepreneurial } \\
\text { Activity }\end{array}$ & $\begin{array}{l}\text { New business VAT registrations per } 1000 \\
\text { population }\end{array}$ & Business Demography \\
\hline Institutions & $\begin{array}{l}\text { Law Enforcement Quality } \\
\text { Law Enforcement Quality }\end{array}$ & $\begin{array}{l}\text { Proportion of Schools rated as good or } \\
\text { above }\end{array}$ & $\begin{array}{l}\text { Home Office Statistics and } \\
\text { Scottish Policing Performance } \\
\text { Framework } \\
\text { Her Majesty's Inspectorate of } \\
\text { Constabulary and Scottish } \\
\text { Policing Performance Framework } \\
\text { Department for Education, } \\
\text { Schools Census results and } \\
\text { Summary Statistics for Schools in } \\
\text { Scotland } \\
\text { Office for Standards in Education, } \\
\text { Children's Services and Skills } \\
\text { (Ofsted), Estyn and School Estate } \\
\text { Statistics } \\
\text { NHS England, National Survey } \\
\text { for Wales, 2013-14 - Health - } \\
\text { experience of GP services and } \\
\text { Scottish Health and Care } \\
\text { Experience Survev }\end{array}$ \\
\hline
\end{tabular}


Table 1: continued

\begin{tabular}{llll}
\hline Dimension & Construct & Measure & Source \\
\hline & Economic Conditions & Population Growth 2004 to 2010 & $\begin{array}{l}\text { Mid-Year Population Estimates } \\
\text { (NOMIS) }\end{array}$ \\
& Economic Conditions & Gross Weekly Income Growth 2008 to 2010 & $\begin{array}{l}\text { Annual Survey of Hours and } \\
\text { Earnings }\end{array}$ \\
$\begin{array}{l}\text { Economic Conditions and } \\
\text { Structural Factors }\end{array}$ & Economic Conditions & $\begin{array}{l}\text { Change in Unemployment Claimant Rate } \\
2010 \text { compared to preceding 5 years }\end{array}$ & NOMIS \\
& Industry Structure & Industry Diversity & ONS Business Demography \\
& Industry Structure & Industry Specialization & ONS Business Demography \\
\hline
\end{tabular}


Table 1: continued

\begin{tabular}{|c|c|c|c|}
\hline Dimension & Construct & Measure & Source \\
\hline \multirow{6}{*}{ Identifying Variables } & $\begin{array}{l}\text { Community Culture } \\
\text { Equation only }\end{array}$ & Proportion Aged 65 Years or Older & $\begin{array}{l}\text { Mid-Year Population Estimates } \\
\text { (NOMIS) }\end{array}$ \\
\hline & $\begin{array}{l}\text { Existing Entrepreneurship } \\
\text { Equation only }\end{array}$ & $\begin{array}{l}\text { Proportion of Workforce Employed as } 1 \\
\text { Managers, directors and senior officials } \\
\text { (SOC2010) }\end{array}$ & Annual Population Survey \\
\hline & $\begin{array}{l}\text { Existing Entrepreneurship } \\
\text { Equation only }\end{array}$ & $\begin{array}{l}\text { Proportion of Workforce Employed in } 2 \\
\text { Professional Occupations (SOC2010) }\end{array}$ & Annual Population Survey \\
\hline & $\begin{array}{l}\text { New Entrepreneurship } \\
\text { Equation only }\end{array}$ & Proportion Aged 35 to 44 Years & $\begin{array}{l}\text { Mid-Year Population Estimates } \\
\text { (NOMIS) }\end{array}$ \\
\hline & Institutions Equation only & $\begin{array}{l}\text { Proportion of population suffering from } \\
\text { poor health }\end{array}$ & Census \\
\hline & Institutions Equation only & Proportion of Population in Education & Census \\
\hline
\end{tabular}


Table 2: OLS Regressions of New Entrepreneurship

\begin{tabular}{|c|c|c|c|c|c|}
\hline & Model 1 & Model 2 & Model 3 & Model 4 & Model 5 \\
\hline $\begin{array}{l}\text { Engagement with } \\
\text { Education and Work }\end{array}$ & $\begin{array}{l}-0.0564 \\
(0.399)\end{array}$ & & & & \\
\hline Social Cohesion & & $\begin{array}{r}-0.6540 \\
(0.000)\end{array}$ & & & \\
\hline $\begin{array}{l}\text { Femininity and Caring } \\
\text { Activities }\end{array}$ & & & $\begin{array}{c}-0.3696 \\
(0.000)\end{array}$ & & \\
\hline Adherence to Social Rules & & & & $\begin{array}{l}-0.2980 \\
(0.000)\end{array}$ & \\
\hline Collective Activities & & & & & $\begin{array}{r}-0.0202 \\
(0.781)\end{array}$ \\
\hline Existing Entrepreneurship & $\begin{array}{c}15.1824 \\
(0.000)\end{array}$ & $\begin{array}{l}14.4335 \\
(0.000)\end{array}$ & $\begin{array}{l}15.2000 \\
(0.000)\end{array}$ & $\begin{array}{l}15.4358 \\
(0.000)\end{array}$ & $\begin{array}{l}15.1259 \\
(0.000)\end{array}$ \\
\hline Institutions & $\begin{array}{l}1.0008 \\
(0.000)\end{array}$ & $\begin{array}{l}0.7988 \\
(0.000)\end{array}$ & $\begin{array}{l}0.8803 \\
(0.000)\end{array}$ & $\begin{array}{l}0.9825 \\
(0.000)\end{array}$ & $\begin{array}{l}0.9240 \\
(0.000)\end{array}$ \\
\hline Population Growth & $\begin{array}{l}6.0557 \\
(0.000)\end{array}$ & $\begin{array}{c}-1.0633 \\
(0.517)\end{array}$ & $\begin{array}{l}3.9954 \\
(0.008)\end{array}$ & $\begin{array}{l}4.6677 \\
(0.002)\end{array}$ & $\begin{array}{l}6.1506 \\
(0.000)\end{array}$ \\
\hline Income Growth & $\begin{array}{l}-2.1148 \\
(0.041)\end{array}$ & $\begin{array}{l}-2.3171 \\
(0.015)\end{array}$ & $\begin{array}{l}-2.4280 \\
(0.015)\end{array}$ & $\begin{array}{l}-2.3599 \\
(0.020)\end{array}$ & $\begin{array}{l}-2.0860 \\
(0.046)\end{array}$ \\
\hline Change in Unemployment & $\begin{array}{l}0.8662 \\
(0.000)\end{array}$ & $\begin{array}{l}0.9394 \\
(0.000)\end{array}$ & $\begin{array}{l}0.7693 \\
(0.000)\end{array}$ & $\begin{array}{l}0.5933 \\
(0.002)\end{array}$ & $\begin{array}{l}0.9229 \\
(0.000)\end{array}$ \\
\hline Industrial Specialization & $\begin{array}{l}-0.7079 \\
(0.291)\end{array}$ & $\begin{array}{l}-0.7337 \\
(0.234)\end{array}$ & $\begin{array}{l}-0.8340 \\
(0.195)\end{array}$ & $\begin{array}{l}-0.7888 \\
(0.228)\end{array}$ & $\begin{array}{l}-0.6380 \\
(0.347)\end{array}$ \\
\hline Industrial Diversity & $\begin{array}{l}-8.3174 \\
(0.000)\end{array}$ & $\begin{array}{l}-4.4241 \\
(0.001)\end{array}$ & $\begin{array}{l}-6.8451 \\
(0.000)\end{array}$ & $\begin{array}{c}-7.0046 \\
(0.000)\end{array}$ & $\begin{array}{l}-8.7203 \\
(0.000)\end{array}$ \\
\hline $\begin{array}{l}\text { Proportion in Prime Age } \\
\text { Group }\end{array}$ & $\begin{array}{l}0.4739 \\
(0.000)\end{array}$ & $\begin{array}{l}0.3430 \\
(0.000)\end{array}$ & $\begin{array}{l}0.3810 \\
(0.000)\end{array}$ & $\begin{array}{l}0.4334 \\
(0.000)\end{array}$ & $\begin{array}{l}0.4629 \\
(0.000)\end{array}$ \\
\hline Constant & $\begin{array}{l}-1.8047 \\
(0.156)\end{array}$ & $\begin{array}{l}-2.1171 \\
(0.051)\end{array}$ & $\begin{array}{c}-1.2433 \\
(0.270)\end{array}$ & $\begin{array}{c}-1.9035 \\
(0.099)\end{array}$ & $\begin{array}{l}-1.3601 \\
(0.250)\end{array}$ \\
\hline$N$ & 374 & 374 & 374 & 374 & 374 \\
\hline F-test & $\begin{array}{c}183.5 \\
(0.000)\end{array}$ & $\begin{array}{c}223.7 \\
(0.000)\end{array}$ & $\begin{array}{c}202.4 \\
(0.000)\end{array}$ & $\begin{array}{c}194.1 \\
(0.000)\end{array}$ & $\begin{array}{c}183.1 \\
(0.000)\end{array}$ \\
\hline$R^{2}$ & 0.819 & 0.847 & 0.834 & 0.828 & 0.819 \\
\hline
\end{tabular}

p-values in parentheses 
Table 3: OLS Regressions of Existing Entrepreneurship

\begin{tabular}{|c|c|c|c|c|c|}
\hline & Model 6 & Model 7 & Model 8 & Model 9 & $\begin{array}{c}\text { Model } \\
10 \\
\end{array}$ \\
\hline $\begin{array}{l}\text { Engagement with Education } \\
\text { and Work }\end{array}$ & $\begin{array}{l}-0.0036 \\
(0.320)\end{array}$ & & & & \\
\hline Social Cohesion & & $\begin{array}{l}0.0257 \\
(0.000)\end{array}$ & & & \\
\hline $\begin{array}{l}\text { Femininity and Caring } \\
\text { Activities }\end{array}$ & & & $\begin{array}{l}0.0207 \\
(0.000)\end{array}$ & & \\
\hline Adherence to Social Rules & & & & $\begin{array}{l}0.0196 \\
(0.000)\end{array}$ & \\
\hline Collective Activities & & & & & $\begin{array}{r}-0.0106 \\
(0.010)\end{array}$ \\
\hline New Entrepreneurship & $\begin{array}{l}0.0397 \\
(0.000)\end{array}$ & $\begin{array}{l}0.0435 \\
(0.000)\end{array}$ & $\begin{array}{l}0.0421 \\
(0.000)\end{array}$ & $\begin{array}{l}0.0409 \\
(0.000)\end{array}$ & $\begin{array}{l}0.0387 \\
(0.000)\end{array}$ \\
\hline Institutions & $\begin{array}{c}-0.0351 \\
(0.007)\end{array}$ & $\begin{array}{r}-0.0346 \\
(0.004)\end{array}$ & $\begin{array}{c}-0.0349 \\
(0.004)\end{array}$ & $\begin{array}{l}-0.0413 \\
(0.001)\end{array}$ & $\begin{array}{l}-0.0530 \\
(0.000)\end{array}$ \\
\hline Population Growth & $\begin{array}{c}-0.5383 \\
(0.000)\end{array}$ & $\begin{array}{c}-0.2490 \\
(0.009)\end{array}$ & $\begin{array}{c}-0.3814 \\
(0.000)\end{array}$ & $\begin{array}{c}-0.4279 \\
(0.000)\end{array}$ & $\begin{array}{l}-0.5671 \\
(0.000)\end{array}$ \\
\hline Income Growth & $\begin{array}{l}0.0062 \\
(0.916)\end{array}$ & $\begin{array}{l}0.0219 \\
(0.698)\end{array}$ & $\begin{array}{l}0.0323 \\
(0.566)\end{array}$ & $\begin{array}{l}0.0263 \\
(0.643)\end{array}$ & $\begin{array}{l}0.0181 \\
(0.756)\end{array}$ \\
\hline Change in Unemployment & $\begin{array}{c}-0.1138 \\
(0.000)\end{array}$ & $\begin{array}{c}-0.1093 \\
(0.000)\end{array}$ & $\begin{array}{c}-0.0989 \\
(0.000)\end{array}$ & $\begin{array}{c}-0.0890 \\
(0.000)\end{array}$ & $\begin{array}{l}-0.1026 \\
(0.000)\end{array}$ \\
\hline Industrial Specialization & $\begin{array}{l}0.0567 \\
(0.132)\end{array}$ & $\begin{array}{c}0.0646 \\
(0.076)\end{array}$ & $\begin{array}{c}0.0677 \\
(0.061)\end{array}$ & $\begin{array}{c}0.0624 \\
(0.087)\end{array}$ & $\begin{array}{l}0.0729 \\
(0.054)\end{array}$ \\
\hline Industrial Diversity & $\begin{array}{l}0.3873 \\
(0.000)\end{array}$ & $\begin{array}{c}0.2470 \\
(0.001)\end{array}$ & $\begin{array}{c}0.2818 \\
(0.000)\end{array}$ & $\begin{array}{c}0.2511 \\
(0.001)\end{array}$ & $\begin{array}{l}0.3468 \\
(0.000)\end{array}$ \\
\hline $\begin{array}{l}\text { Employment in Managerial } \\
\text { Positions }\end{array}$ & $\begin{array}{l}0.0024 \\
(0.048)\end{array}$ & $\begin{array}{c}0.0017 \\
(0.147)\end{array}$ & $\begin{array}{l}0.0018 \\
(0.108)\end{array}$ & $\begin{array}{c}0.0010 \\
(0.416)\end{array}$ & $\begin{array}{l}0.0016 \\
(0.188)\end{array}$ \\
\hline $\begin{array}{l}\text { Employment in Professional } \\
\text { Positions }\end{array}$ & $\begin{array}{l}-0.0013 \\
(0.073)\end{array}$ & $\begin{array}{l}-0.0007 \\
(0.347)\end{array}$ & $\begin{array}{l}-0.0011 \\
(0.108)\end{array}$ & $\begin{array}{l}-0.0014 \\
(0.045)\end{array}$ & $\begin{array}{l}-0.0011 \\
(0.133)\end{array}$ \\
\hline Constant & $\begin{array}{l}-0.0190 \\
(0.793)\end{array}$ & $\begin{array}{l}0.0372 \\
(0.582)\end{array}$ & $\begin{array}{l}0.0208 \\
(0.755)\end{array}$ & $\begin{array}{l}0.0634 \\
(0.355)\end{array}$ & $\begin{array}{l}0.0193 \\
(0.781)\end{array}$ \\
\hline$N$ & 374 & 374 & 374 & 374 & 374 \\
\hline F-test & $\begin{array}{c}149.9 \\
(0.000)\end{array}$ & $\begin{array}{c}163.1 \\
(0.000)\end{array}$ & $\begin{array}{c}166.2 \\
(0.000)\end{array}$ & $\begin{array}{c}162.0 \\
(0.000)\end{array}$ & $\begin{array}{l}152.8 \\
(0.000)\end{array}$ \\
\hline$R^{2}$ & 0.805 & 0.818 & 0.821 & 0.817 & 0.808 \\
\hline
\end{tabular}

p-values in parentheses 
Table 4: TSLS regressions of new and existing entrepreneurship, institutions and culture

\begin{tabular}{|c|c|c|c|c|c|}
\hline & & $\begin{array}{c}\text { New } \\
\text { Entrepreneurship }\end{array}$ & $\begin{array}{c}\text { Existing } \\
\text { Entrepreneurship }\end{array}$ & Institutions & Culture \\
\hline \multirow{4}{*}{$\begin{array}{l}\text { Engagement } \\
\text { with Education } \\
\text { and Work }\end{array}$} & Culture & $\begin{array}{c}-0.0496 \\
(0.766)\end{array}$ & $\begin{array}{l}0.0050 \\
(0.699)\end{array}$ & $\begin{array}{l}0.0037 \\
(0.956)\end{array}$ & \\
\hline & $\begin{array}{l}\text { New } \\
\text { Entrepreneurship }\end{array}$ & & $\begin{array}{l}0.0101 \\
(0.239)\end{array}$ & $\begin{array}{l}0.0593 \\
(0.047)\end{array}$ & $\begin{array}{l}0.0134 \\
(0.974)\end{array}$ \\
\hline & Existing Entre’ & $\begin{array}{c}17.5730 \\
(0.000)\end{array}$ & & $\begin{array}{l}-2.0293 \\
(0.050)\end{array}$ & $\begin{array}{l}0.8928 \\
(0.930)\end{array}$ \\
\hline & Institutions & $\begin{array}{l}-0.3568 \\
(0.770)\end{array}$ & $\begin{array}{l}0.1737 \\
(0.110)\end{array}$ & & $\begin{array}{l}5.2714 \\
(0.001)\end{array}$ \\
\hline \multirow{4}{*}{ Social Cohesion } & Culture & $\begin{array}{l}-0.8648 \\
(0.000)\end{array}$ & $\begin{array}{l}0.0691 \\
(0.000)\end{array}$ & $\begin{array}{l}-0.1283 \\
(0.367)\end{array}$ & \\
\hline & $\begin{array}{l}\text { New } \\
\text { Entrepreneurship }\end{array}$ & & $\begin{array}{l}0.0270 \\
(0.004)\end{array}$ & $\begin{array}{l}0.0101 \\
(0.892)\end{array}$ & $\begin{array}{l}-0.0226 \\
(0.874)\end{array}$ \\
\hline & $\begin{array}{l}\text { Existing } \\
\text { Entrepreneurship }\end{array}$ & $\begin{array}{l}17.7532 \\
(0.000)\end{array}$ & & $\begin{array}{l}-1.3876 \\
(0.359)\end{array}$ & $\begin{array}{l}-1.9409 \\
(0.577)\end{array}$ \\
\hline & Institutions & $\begin{array}{l}-0.8941 \\
(0.318)\end{array}$ & $\begin{array}{l}0.1786 \\
(0.046)\end{array}$ & & $\begin{array}{l}0.5303 \\
(0.293)\end{array}$ \\
\hline \multirow{4}{*}{$\begin{array}{l}\text { Femininity and } \\
\text { Caring } \\
\text { Activities }\end{array}$} & Culture & $\begin{array}{l}-0.6179 \\
(0.000)\end{array}$ & $\begin{array}{l}0.0435 \\
(0.000)\end{array}$ & $\begin{array}{l}-0.0757 \\
(0.192)\end{array}$ & \\
\hline & $\begin{array}{l}\text { New } \\
\text { Entrepreneurship }\end{array}$ & & $\begin{array}{l}0.0215 \\
(0.010)\end{array}$ & $\begin{array}{l}0.0191 \\
(0.694)\end{array}$ & $\begin{array}{l}0.1664 \\
(0.389)\end{array}$ \\
\hline & $\begin{array}{l}\text { Existing } \\
\text { Entrepreneurship }\end{array}$ & $\begin{array}{l}19.6507 \\
(0.000)\end{array}$ & & $\begin{array}{l}-1.2727 \\
(0.318)\end{array}$ & $\begin{array}{l}-4.0709 \\
(0.388)\end{array}$ \\
\hline & Institutions & $\begin{array}{l}-0.9955 \\
(0.303)\end{array}$ & $\begin{array}{l}0.1734 \\
(0.031)\end{array}$ & & $\begin{array}{l}0.5904 \\
(0.387)\end{array}$ \\
\hline \multirow{4}{*}{$\begin{array}{l}\text { Adherence to } \\
\text { Social Rules }\end{array}$} & Culture & $\begin{array}{l}-0.7262 \\
(0.001)\end{array}$ & $\begin{array}{l}0.0537 \\
(0.000)\end{array}$ & $\begin{array}{l}-0.0657 \\
(0.567)\end{array}$ & \\
\hline & $\begin{array}{l}\text { New } \\
\text { Entrepreneurship }\end{array}$ & & $\begin{array}{l}0.0204 \\
(0.003)\end{array}$ & $\begin{array}{l}0.0292 \\
(0.656)\end{array}$ & $\begin{array}{l}-0.1235 \\
(0.542)\end{array}$ \\
\hline & $\begin{array}{l}\text { Existing } \\
\text { Entrepreneurship }\end{array}$ & $\begin{array}{c}20.5720 \\
(0.000)\end{array}$ & & $\begin{array}{l}-1.3684 \\
(0.451)\end{array}$ & $\begin{array}{l}5.0042 \\
(0.303)\end{array}$ \\
\hline & Institutions & $\begin{array}{l}0.4917 \\
(0.608)\end{array}$ & $\begin{array}{l}0.0436 \\
(0.553)\end{array}$ & & $\begin{array}{l}1.9753 \\
(0.008)\end{array}$ \\
\hline \multirow{4}{*}{$\begin{array}{l}\text { Collective } \\
\text { Action }\end{array}$} & Culture & $\begin{array}{l}0.6297 \\
(0.001)\end{array}$ & $\begin{array}{l}-0.0470 \\
(0.000)\end{array}$ & $\begin{array}{l}-0.1173 \\
(0.109)\end{array}$ & \\
\hline & $\begin{array}{l}\text { New } \\
\text { Entrepreneurship }\end{array}$ & & $\begin{array}{l}0.0203 \\
(0.002)\end{array}$ & $\begin{array}{l}0.0811 \\
(0.008)\end{array}$ & $\begin{array}{l}0.2303 \\
(0.343)\end{array}$ \\
\hline & $\begin{array}{l}\text { Existing } \\
\text { Entrepreneurship }\end{array}$ & $\begin{array}{c}20.8519 \\
(0.000)\end{array}$ & & $\begin{array}{l}-2.4701 \\
(0.009)\end{array}$ & $\begin{array}{l}-8.2653 \\
(0.173)\end{array}$ \\
\hline & Institutions & $\begin{array}{l}2.6167 \\
(0.043)\end{array}$ & $\begin{array}{l}-0.1293 \\
(0.129)\end{array}$ & & $\begin{array}{l}-5.5846 \\
(0.000)\end{array}$ \\
\hline
\end{tabular}

p-values in parentheses 
Table 5: TSLS regressions of new and existing entrepreneurship, institutions and culture

\begin{tabular}{|c|c|c|c|c|c|}
\hline & & $\begin{array}{c}\text { New } \\
\text { Entrepreneurship }\end{array}$ & $\begin{array}{c}\text { Existing } \\
\text { Entrepreneurship }\end{array}$ & Institutions & Culture \\
\hline \multirow{4}{*}{$\begin{array}{l}\text { Absences from } \\
\text { Secondary } \\
\text { School }\end{array}$} & Culture & $\begin{array}{l}0.0749 \\
(0.000)\end{array}$ & $\begin{array}{l}-0.0044 \\
(0.026)\end{array}$ & $\begin{array}{c}-0.0023 \\
(0.817)\end{array}$ & \\
\hline & $\begin{array}{l}\text { New } \\
\text { Entrepreneurship }\end{array}$ & & $\begin{array}{l}0.0213 \\
(0.035)\end{array}$ & $\begin{array}{l}0.0676 \\
(0.071)\end{array}$ & $\begin{array}{l}0.7732 \\
(0.741)\end{array}$ \\
\hline & $\begin{array}{l}\text { Existing } \\
\text { Entrepreneurship }\end{array}$ & $\begin{array}{l}15.2790 \\
(0.000)\end{array}$ & & $\begin{array}{l}-2.2592 \\
(0.019)\end{array}$ & $\begin{array}{c}29.3351 \\
(0.603)\end{array}$ \\
\hline & Institutions & $\begin{array}{l}-2.0108 \\
(0.041)\end{array}$ & $\begin{array}{l}0.2792 \\
(0.004)\end{array}$ & & $\begin{array}{c}14.2748 \\
(0.116)\end{array}$ \\
\hline \multirow{4}{*}{$\begin{array}{l}\text { Ethnic } \\
\text { Similarity }\end{array}$} & Culture & $\begin{array}{l}-0.0435 \\
(0.000)\end{array}$ & $\begin{array}{l}0.0029 \\
(0.000)\end{array}$ & $\begin{array}{l}-0.0078 \\
(0.290)\end{array}$ & \\
\hline & $\begin{array}{l}\text { New } \\
\text { Entrepreneurship }\end{array}$ & & $\begin{array}{l}0.0307 \\
(0.000)\end{array}$ & $\begin{array}{l}-0.0251 \\
(0.789)\end{array}$ & $\begin{array}{l}-2.9939 \\
(0.295)\end{array}$ \\
\hline & $\begin{array}{l}\text { Existing } \\
\text { Entrepreneurship }\end{array}$ & $\begin{array}{l}19.1821 \\
(0.000)\end{array}$ & & $\begin{array}{l}-0.4484 \\
(0.828)\end{array}$ & $\begin{array}{c}38.8894 \\
(0.577)\end{array}$ \\
\hline & Institutions & $\begin{array}{l}-1.0773 \\
(0.241)\end{array}$ & $\begin{array}{l}0.1456 \\
(0.071)\end{array}$ & & $\begin{array}{l}2.9805 \\
(0.770)\end{array}$ \\
\hline \multirow{4}{*}{$\begin{array}{l}\text { Proportion of } \\
\text { Female } \\
\text { Employment } \\
\text { which is Part- } \\
\text { Time }\end{array}$} & Culture & $\begin{array}{l}-0.1176 \\
(0.000)\end{array}$ & $\begin{array}{l}0.0069 \\
(0.000)\end{array}$ & $\begin{array}{l}-0.0158 \\
(0.186)\end{array}$ & \\
\hline & $\begin{array}{l}\text { New } \\
\text { Entrepreneurship }\end{array}$ & & $\begin{array}{l}0.0301 \\
(0.000)\end{array}$ & $\begin{array}{l}-0.0103 \\
(0.881)\end{array}$ & $\begin{array}{l}-2.1143 \\
(0.138)\end{array}$ \\
\hline & $\begin{array}{l}\text { Existing } \\
\text { Entrepreneurship }\end{array}$ & $\begin{array}{c}20.8164 \\
(0.000)\end{array}$ & & $\begin{array}{l}-0.6057 \\
(0.721)\end{array}$ & $\begin{array}{c}48.8063 \\
(0.153)\end{array}$ \\
\hline & Institutions & $\begin{array}{l}-0.4709 \\
(0.630)\end{array}$ & $\begin{array}{l}0.0884 \\
(0.201)\end{array}$ & & $\begin{array}{l}4.4999 \\
(0.399)\end{array}$ \\
\hline \multirow{4}{*}{$\begin{array}{l}\text { Crimes by } \\
\text { Deception } \\
\text { (Inverse) }\end{array}$} & Culture & $\begin{array}{l}-0.0796 \\
(0.000)\end{array}$ & $\begin{array}{l}0.0059 \\
(0.000)\end{array}$ & $\begin{array}{l}-0.0089 \\
(0.278)\end{array}$ & \\
\hline & $\begin{array}{l}\text { New } \\
\text { Entrepreneurship }\end{array}$ & & $\begin{array}{l}0.0202 \\
(0.025)\end{array}$ & $\begin{array}{l}0.0329 \\
(0.474)\end{array}$ & $\begin{array}{l}1.7271 \\
(0.498)\end{array}$ \\
\hline & $\begin{array}{l}\text { Existing } \\
\text { Entrepreneurship }\end{array}$ & $\begin{array}{l}18.9718 \\
(0.000)\end{array}$ & & $\begin{array}{l}-1.7106 \\
(0.144)\end{array}$ & $\begin{array}{c}-48.1393 \\
(0.439)\end{array}$ \\
\hline & Institutions & $\begin{array}{l}-0.1572 \\
(0.870)\end{array}$ & $\begin{array}{l}0.1266 \\
(0.157)\end{array}$ & & $\begin{array}{l}16.1475 \\
(0.074)\end{array}$ \\
\hline \multirow{4}{*}{$\begin{array}{l}\text { Proportion } \\
\text { Voting for Left } \\
\text { of Centre Parties }\end{array}$} & Culture & $\begin{array}{l}0.0360 \\
(0.000)\end{array}$ & $\begin{array}{l}-0.0027 \\
(0.000)\end{array}$ & $\begin{array}{l}-0.0046 \\
(0.460)\end{array}$ & \\
\hline & $\begin{array}{l}\text { New } \\
\text { Entrepreneurship }\end{array}$ & & $\begin{array}{l}0.0227 \\
(0.000)\end{array}$ & $\begin{array}{l}0.0917 \\
(0.133)\end{array}$ & $\begin{array}{l}5.3597 \\
(0.159)\end{array}$ \\
\hline & $\begin{array}{l}\text { Existing } \\
\text { Entrepreneurship }\end{array}$ & $\begin{array}{c}21.2242 \\
(0.000)\end{array}$ & & $\begin{array}{l}-3.0151 \\
(0.087)\end{array}$ & $\begin{array}{c}-186.0533 \\
(0.042)\end{array}$ \\
\hline & Institutions & $\begin{array}{l}1.4297 \\
(0.179)\end{array}$ & $\begin{array}{l}-0.0577 \\
(0.424)\end{array}$ & & $\begin{array}{c}-62.2377 \\
(0.000)\end{array}$ \\
\hline
\end{tabular}

p-values in parentheses 
Table 6: TSLS regressions of new and existing entrepreneurship, institutions and culture with interactions between culture and the change in unemployment

\begin{tabular}{|c|c|c|c|c|c|}
\hline & & $\begin{array}{c}\text { New } \\
\text { Entrepreneurship }\end{array}$ & $\begin{array}{c}\text { Existing } \\
\text { Entrepreneurship }\end{array}$ & Institutions & Culture \\
\hline \multirow{6}{*}{$\begin{array}{l}\text { Engagement } \\
\text { with } \\
\text { Education } \\
\text { and Work }\end{array}$} & Culture & $\begin{array}{l}-1.4540 \\
(0.016)\end{array}$ & $\begin{array}{l}-0.0186 \\
(0.010)\end{array}$ & $\begin{array}{l}0.0523 \\
(0.061)\end{array}$ & \\
\hline & $\begin{array}{l}\text { Culture*Change } \\
\text { in Unemployment }\end{array}$ & $\begin{array}{l}1.3050 \\
(0.005)\end{array}$ & & & \\
\hline & $\begin{array}{l}\text { New } \\
\text { Entrepreneurship }\end{array}$ & & $\begin{array}{l}0.0344 \\
(0.000)\end{array}$ & $\begin{array}{l}0.0499 \\
(0.069)\end{array}$ & $\begin{array}{l}1.0721 \\
(0.007)\end{array}$ \\
\hline & $\begin{array}{l}\text { Existing } \\
\text { Entrepreneurship }\end{array}$ & $\begin{array}{c}22.6431 \\
(0.000)\end{array}$ & & $\begin{array}{l}-1.4812 \\
(0.120)\end{array}$ & $\begin{array}{r}-30.6587 \\
(0.000)\end{array}$ \\
\hline & Institutions & $\begin{array}{l}-0.9603 \\
(0.488)\end{array}$ & $\begin{array}{l}0.1178 \\
(0.153)\end{array}$ & & $\begin{array}{l}7.5367 \\
(0.000)\end{array}$ \\
\hline & $\begin{array}{l}\text { Change in } \\
\text { Unemployment }\end{array}$ & $\begin{array}{l}2.4606 \\
(0.000)\end{array}$ & $\begin{array}{l}-0.1289 \\
(0.000)\end{array}$ & $\begin{array}{l}-0.0949 \\
(0.416)\end{array}$ & $\begin{array}{l}-4.0291 \\
(0.000)\end{array}$ \\
\hline \multirow{6}{*}{$\begin{array}{l}\text { Social } \\
\text { Cohesion }\end{array}$} & Culture & $\begin{array}{l}-1.2393 \\
(0.000)\end{array}$ & $\begin{array}{l}0.0520 \\
(0.000)\end{array}$ & $\begin{array}{l}-0.0466 \\
(0.201)\end{array}$ & \\
\hline & $\begin{array}{l}\text { Culture*Change } \\
\text { in Unemployment }\end{array}$ & $\begin{array}{l}0.2230 \\
(0.386)\end{array}$ & & & \\
\hline & $\begin{array}{l}\text { New } \\
\text { Entrepreneurship }\end{array}$ & & $\begin{array}{l}0.0464 \\
(0.000)\end{array}$ & $\begin{array}{l}0.0535 \\
(0.093)\end{array}$ & $\begin{array}{l}-0.8346 \\
(0.000)\end{array}$ \\
\hline & $\begin{array}{l}\text { Existing } \\
\text { Entrepreneurship }\end{array}$ & $\begin{array}{l}18.7388 \\
(0.000)\end{array}$ & & $\begin{array}{l}-2.1987 \\
(0.011)\end{array}$ & $\begin{array}{l}16.3156 \\
(0.000)\end{array}$ \\
\hline & Institutions & $\begin{array}{l}-0.3537 \\
(0.672)\end{array}$ & $\begin{array}{l}0.0372 \\
(0.548)\end{array}$ & & $\begin{array}{l}-0.2709 \\
(0.770)\end{array}$ \\
\hline & $\begin{array}{l}\text { Change in } \\
\text { Unemployment }\end{array}$ & $\begin{array}{l}1.7369 \\
(0.000)\end{array}$ & $\begin{array}{l}-0.1044 \\
(0.000)\end{array}$ & $\begin{array}{l}-0.1857 \\
(0.084)\end{array}$ & $\begin{array}{l}1.6651 \\
(0.000)\end{array}$ \\
\hline \multirow{6}{*}{$\begin{array}{l}\text { Feminine } \\
\text { and Caring } \\
\text { Activities }\end{array}$} & Culture & $\begin{array}{l}-1.1406 \\
(0.051)\end{array}$ & $\begin{array}{l}0.0483 \\
(0.000)\end{array}$ & $\begin{array}{l}-0.0783 \\
(0.001)\end{array}$ & \\
\hline & $\begin{array}{l}\text { Culture*Change } \\
\text { in Unemployment }\end{array}$ & $\begin{array}{l}0.2759 \\
(0.636)\end{array}$ & & & \\
\hline & $\begin{array}{l}\text { New } \\
\text { Entrepreneurship }\end{array}$ & & $\begin{array}{l}0.0416 \\
(0.000)\end{array}$ & $\begin{array}{l}0.0085 \\
(0.776)\end{array}$ & $\begin{array}{l}-0.7895 \\
(0.001)\end{array}$ \\
\hline & $\begin{array}{l}\text { Existing } \\
\text { Entrepreneurship }\end{array}$ & $\begin{array}{c}21.0111 \\
(0.000)\end{array}$ & & $\begin{array}{l}-1.0112 \\
(0.240)\end{array}$ & $\begin{array}{l}17.6028 \\
(0.003)\end{array}$ \\
\hline & Institutions & $\begin{array}{l}-1.3754 \\
(0.140)\end{array}$ & $\begin{array}{l}0.0905 \\
(0.210)\end{array}$ & & $\begin{array}{l}-1.3590 \\
(0.194)\end{array}$ \\
\hline & $\begin{array}{l}\text { Change in } \\
\text { Unemployment }\end{array}$ & $\begin{array}{l}1.5842 \\
(0.000)\end{array}$ & $\begin{array}{l}-0.0791 \\
(0.000)\end{array}$ & $\begin{array}{l}-0.0968 \\
(0.357)\end{array}$ & $\begin{array}{l}1.3243 \\
(0.027)\end{array}$ \\
\hline
\end{tabular}

p-values in parentheses 
Table 6: Continued

\begin{tabular}{|c|c|c|c|c|c|}
\hline & & $\begin{array}{c}\text { New } \\
\text { Entrepreneurship }\end{array}$ & $\begin{array}{c}\text { Existing } \\
\text { Entrepreneurship }\end{array}$ & Institutions & Culture \\
\hline \multirow{6}{*}{$\begin{array}{l}\text { Adherence to } \\
\text { Social Rules }\end{array}$} & Culture & $\begin{array}{l}-0.6477 \\
(0.241)\end{array}$ & $\begin{array}{l}0.0081 \\
(0.183)\end{array}$ & $\begin{array}{l}0.1312 \\
(0.000)\end{array}$ & \\
\hline & $\begin{array}{l}\text { Culture*Change } \\
\text { in Unemployment }\end{array}$ & $\begin{array}{l}0.1867 \\
(0.656)\end{array}$ & & & \\
\hline & $\begin{array}{l}\text { New } \\
\text { Entrepreneurship }\end{array}$ & & $\begin{array}{l}0.0166 \\
(0.035)\end{array}$ & $\begin{array}{l}0.1195 \\
(0.000)\end{array}$ & $\begin{array}{l}-0.2748 \\
(0.126)\end{array}$ \\
\hline & $\begin{array}{l}\text { Existing } \\
\text { Entrepreneurship }\end{array}$ & $\begin{array}{c}21.0817 \\
(0.000)\end{array}$ & & $\begin{array}{l}-3.3775 \\
(0.000)\end{array}$ & $\begin{array}{l}6.5301 \\
(0.138)\end{array}$ \\
\hline & Institutions & $\begin{array}{l}-0.0332 \\
(0.971)\end{array}$ & $\begin{array}{l}0.1534 \\
(0.057)\end{array}$ & & $\begin{array}{l}1.7842 \\
(0.011)\end{array}$ \\
\hline & $\begin{array}{l}\text { Change in } \\
\text { Unemployment }\end{array}$ & $\begin{array}{l}1.4798 \\
(0.000)\end{array}$ & $\begin{array}{l}-0.1112 \\
(0.000)\end{array}$ & $\begin{array}{l}-0.1530 \\
(0.141)\end{array}$ & $\begin{array}{l}-0.3385 \\
(0.430)\end{array}$ \\
\hline \multirow{6}{*}{$\begin{array}{l}\text { Collective } \\
\text { Activities }\end{array}$} & Culture & $\begin{array}{l}1.1741 \\
(0.037)\end{array}$ & $\begin{array}{l}-0.0516 \\
(0.000)\end{array}$ & $\begin{array}{l}-0.1643 \\
(0.000)\end{array}$ & \\
\hline & $\begin{array}{l}\text { Culture*Change } \\
\text { in Unemployment }\end{array}$ & $\begin{array}{l}-0.6928 \\
(0.166)\end{array}$ & & & \\
\hline & $\begin{array}{l}\text { New } \\
\text { Entrepreneurship }\end{array}$ & & $\begin{array}{l}0.0314 \\
(0.000)\end{array}$ & $\begin{array}{c}0.0864 \\
(0.000)\end{array}$ & $\begin{array}{l}0.4528 \\
(0.017)\end{array}$ \\
\hline & $\begin{array}{l}\text { Existing } \\
\text { Entrepreneurship }\end{array}$ & $\begin{array}{c}20.0659 \\
(0.000)\end{array}$ & & $\begin{array}{l}-1.9188 \\
(0.002)\end{array}$ & $\begin{array}{c}-12.5646 \\
(0.004)\end{array}$ \\
\hline & Institutions & $\begin{array}{l}3.0436 \\
(0.039)\end{array}$ & $\begin{array}{l}-0.3262 \\
(0.000)\end{array}$ & & $\begin{array}{l}-6.6458 \\
(0.000)\end{array}$ \\
\hline & $\begin{array}{l}\text { Change in } \\
\text { Unemployment }\end{array}$ & $\begin{array}{l}1.6353 \\
(0.001)\end{array}$ & $\begin{array}{l}-0.0743 \\
(0.000)\end{array}$ & $\begin{array}{l}-0.0983 \\
(0.243)\end{array}$ & $\begin{array}{l}-0.7513 \\
(0.110)\end{array}$ \\
\hline
\end{tabular}

$\mathrm{p}$-values in parentheses 
APPENDIX TABLES

Table A1: Factor Analysis of Cultural Components

\begin{tabular}{|c|c|c|c|c|c|c|}
\hline & $\begin{array}{r}\text { Engagen } \\
\text { Education } \\
\text { Component } \\
1\end{array}$ & $\begin{array}{l}\text { ent with } \\
\text { and Work } \\
\text { Component } \\
2\end{array}$ & $\begin{array}{c}\text { Social } \\
\text { Cohesion } \\
\text { Component } \\
1\end{array}$ & $\begin{array}{c}\text { Feminine } \\
\text { and Caring } \\
\text { Activities } \\
\text { Component } \\
1\end{array}$ & $\begin{array}{c}\text { Adherence } \\
\text { to Social } \\
\text { Rules } \\
\text { Component } \\
1\end{array}$ & $\begin{array}{c}\text { Collective } \\
\text { Activities } \\
\text { Component } \\
1\end{array}$ \\
\hline NVQ level 4 & 0.074 & 0.917 & & & & \\
\hline $\begin{array}{l}\text { No Formal Education } \\
\text { (inverse) }\end{array}$ & 0.349 & 0.816 & & & & \\
\hline Male Economic Activity & 0.703 & 0.201 & & & & \\
\hline $\begin{array}{l}\text { Primary School } \\
\text { Absences (Inverse) }\end{array}$ & 0.792 & 0.229 & & & & \\
\hline $\begin{array}{l}\text { Secondary School } \\
\text { Absences (Inverse) }\end{array}$ & 0.806 & 0.076 & & & & \\
\hline Proportion born in UK & & & 0.932 & & & \\
\hline $\begin{array}{l}\text { Proportion identifying } \\
\text { with country }\end{array}$ & & & 0.858 & & & \\
\hline Religious Similarity & & & 0.860 & & & \\
\hline Ethnic Similarity & & & 0.954 & & & \\
\hline $\begin{array}{l}\text { Gross Migration Flow } \\
\text { (inverse) } \\
\text { Proportion of Female }\end{array}$ & & & 0.755 & & & \\
\hline Employment which is & & & & 0.856 & & \\
\hline Part-Time & & & & & & \\
\hline $\begin{array}{l}\text { Provision of Unpaid } \\
\text { Care }\end{array}$ & & & & 0.646 & & \\
\hline $\begin{array}{l}\text { Female Economic } \\
\text { Activity }\end{array}$ & & & & 0.610 & & \\
\hline $\begin{array}{l}\text { Alcohol Related Deaths } \\
\text { (Inverse) } \\
\text { Under } 18 \text { Years }\end{array}$ & & & & & 0.688 & \\
\hline $\begin{array}{l}\text { Conception Rates } \\
\text { (inverse) }\end{array}$ & & & & & 0.713 & \\
\hline $\begin{array}{l}\text { Crimes by Deception } \\
\text { (Inverse) }\end{array}$ & & & & & 0.842 & \\
\hline $\begin{array}{l}\text { Non-Sexual Violent } \\
\text { Crimes (Inverse) }\end{array}$ & & & & & 0.839 & \\
\hline $\begin{array}{l}\text { Trade Union } \\
\text { Membership }\end{array}$ & & & & & & 0.881 \\
\hline $\begin{array}{l}\text { Proportion Voting for } \\
\text { Left of Centre Parties }\end{array}$ & & & & & & 0.881 \\
\hline $\begin{array}{c}\text { Percentage of Variance } \\
\text { Extracted }\end{array}$ & 50.1 & 20.0 & 76.4 & 50.7 & 59.9 & 77.6 \\
\hline
\end{tabular}


Table A2: Person Correlation Coefficients for Cultural Component Measures

\begin{tabular}{|c|c|c|c|c|c|c|c|c|c|c|c|c|c|c|c|c|c|}
\hline & $\begin{array}{l}\text { 1. NVQ } \\
\text { Level } 4 \\
\end{array}$ & 2 & 3 & 4 & 5 & 6 & 7 & 8 & 9 & 10 & 11 & 12 & 13 & 14 & 15 & 16 & 17 \\
\hline $\begin{array}{l}2 \text { Male Economic Activity } \\
\text { Rate }\end{array}$ & $\begin{array}{c}0.174 \\
(0.001)\end{array}$ & & & & & & & & & & & & & & & & \\
\hline $\begin{array}{l}3 \text { No Formal Qualifications } \\
\text { (inverse) }\end{array}$ & $\begin{array}{c}0.602 \\
(0.000)\end{array}$ & $\begin{array}{c}0.434 \\
(0.000)\end{array}$ & & & & & & & & & & & & & & & \\
\hline $\begin{array}{l}4 \text { Primary School } \\
\text { Absences (inverse) }\end{array}$ & $\begin{array}{c}0.304 \\
(0.000)\end{array}$ & $\begin{array}{c}0.421 \\
(0.000)\end{array}$ & $\begin{array}{c}0.385 \\
(0.000)\end{array}$ & & & & & & & & & & & & & & \\
\hline $\begin{array}{l}5 \text { Secondary School } \\
\text { Absences (inverse) }\end{array}$ & $\begin{array}{c}0.219 \\
(0.000)\end{array}$ & $\begin{array}{c}0.352 \\
(0.000)\end{array}$ & $\begin{array}{c}0.329 \\
(0.000)\end{array}$ & $\begin{array}{c}0.546 \\
(0.000)\end{array}$ & & & & & & & & & & & & & \\
\hline 6 Born in the UK & $\begin{array}{l}-0.387 \\
(0.000)\end{array}$ & $\begin{array}{c}0.059 \\
(0.252)\end{array}$ & $\begin{array}{l}-0.063 \\
(0.224)\end{array}$ & $\begin{array}{c}0.153 \\
(0.003)\end{array}$ & $\begin{array}{l}-0.154 \\
(0.003)\end{array}$ & & & & & & & & & & & & \\
\hline $\begin{array}{l}7 \text { Identify with Country of } \\
\text { Residence }\end{array}$ & $\begin{array}{c}-0.395 \\
(0.000)\end{array}$ & $\begin{array}{c}0.012 \\
(0.820)\end{array}$ & $\begin{array}{l}-0.214 \\
(0.000)\end{array}$ & $\begin{array}{c}0.096 \\
(0.064)\end{array}$ & $\begin{array}{c}-0.329 \\
(0.000)\end{array}$ & $\begin{array}{c}0.762 \\
(0.000)\end{array}$ & & & & & & & & & & & \\
\hline 8 Religious Similarity & $\begin{array}{l}-0.237 \\
(0.000)\end{array}$ & $\begin{array}{c}0.144 \\
(0.005)\end{array}$ & $\begin{array}{c}0.059 \\
(0.255)\end{array}$ & $\begin{array}{c}0.234 \\
(0.000)\end{array}$ & $\begin{array}{c}-0.012 \\
(0.813)\end{array}$ & $\begin{array}{c}0.746 \\
(0.000)\end{array}$ & $\begin{array}{c}0.620 \\
(0.000)\end{array}$ & & & & & & & & & & \\
\hline 9 Ethnic Similarity & $\begin{array}{c}-0.319 \\
(0.000)\end{array}$ & $\begin{array}{c}0.080 \\
(0.123)\end{array}$ & $\begin{array}{c}0.026 \\
(0.616)\end{array}$ & $\begin{array}{c}0.170 \\
(0.001)\end{array}$ & $\begin{array}{c}-0.191 \\
(0.000)\end{array}$ & $\begin{array}{c}0.892 \\
(0.000)\end{array}$ & $\begin{array}{c}0.756 \\
(0.000)\end{array}$ & $\begin{array}{c}0.868 \\
(0.000)\end{array}$ & & & & & & & & & \\
\hline $\begin{array}{l}10 \text { Female Employment } \\
\text { which is Part-Time }\end{array}$ & $\begin{array}{c}-0.115 \\
(0.026)\end{array}$ & $\begin{array}{c}0.135 \\
(0.009)\end{array}$ & $\begin{array}{c}0.145 \\
(0.005)\end{array}$ & $\begin{array}{c}0.158 \\
(0.002)\end{array}$ & $\begin{array}{c}-0.011 \\
(0.836)\end{array}$ & $\begin{array}{c}0.505 \\
(0.000)\end{array}$ & $\begin{array}{c}0.355 \\
(0.000)\end{array}$ & $\begin{array}{c}0.409 \\
(0.000)\end{array}$ & $\begin{array}{c}0.497 \\
(0.000)\end{array}$ & & & & & & & & \\
\hline $\begin{array}{l}11 \text { Provision of Unpaid } \\
\text { Care }\end{array}$ & $\begin{array}{c}-0.478 \\
(0.000)\end{array}$ & $\begin{array}{l}-0.144 \\
(0.005)\end{array}$ & $\begin{array}{l}-0.216 \\
(0.000)\end{array}$ & $\begin{array}{l}-0.181 \\
(0.000)\end{array}$ & $\begin{array}{l}-0.086 \\
(0.096)\end{array}$ & $\begin{array}{c}0.709 \\
(0.000)\end{array}$ & $\begin{array}{c}0.513 \\
(0.000)\end{array}$ & $\begin{array}{c}0.600 \\
(0.000)\end{array}$ & $\begin{array}{c}0.687 \\
(0.000)\end{array}$ & $\begin{array}{c}0.389 \\
(0.000)\end{array}$ & & & & & & & \\
\hline $\begin{array}{l}12 \text { Female Economic } \\
\text { Activity Rate }\end{array}$ & $\begin{array}{c}0.148 \\
(0.004)\end{array}$ & $\begin{array}{c}0.477 \\
(0.000)\end{array}$ & $\begin{array}{c}0.440 \\
(0.000)\end{array}$ & $\begin{array}{c}0.398 \\
(0.000)\end{array}$ & $\begin{array}{c}0.176 \\
(0.001)\end{array}$ & $\begin{array}{c}0.333 \\
(0.000)\end{array}$ & $\begin{array}{c}0.217 \\
(0.000)\end{array}$ & $\begin{array}{c}0.333 \\
(0.000)\end{array}$ & $\begin{array}{c}0.355 \\
(0.000)\end{array}$ & $\begin{array}{c}0.338 \\
(0.000)\end{array}$ & $\begin{array}{c}0.050 \\
(0.331)\end{array}$ & & & & & & \\
\hline 13 Alcohol Related Deaths & $\begin{array}{l}-0.058 \\
(0.261)\end{array}$ & $\begin{array}{c}0.331 \\
(0.000)\end{array}$ & $\begin{array}{c}0.267 \\
(0.000)\end{array}$ & $\begin{array}{c}0.174 \\
(0.001)\end{array}$ & $\begin{array}{c}0.518 \\
(0.000)\end{array}$ & $\begin{array}{c}0.197 \\
(0.000)\end{array}$ & $\begin{array}{c}-0.042 \\
(0.415)\end{array}$ & $\begin{array}{c}0.188 \\
(0.000)\end{array}$ & $\begin{array}{c}0.174 \\
(0.001)\end{array}$ & $\begin{array}{c}0.285 \\
(0.000)\end{array}$ & $\begin{array}{c}0.242 \\
(0.000)\end{array}$ & $\begin{array}{c}0.199 \\
(0.000)\end{array}$ & & & & & \\
\hline $\begin{array}{l}14 \text { Under } 18 \text { years } \\
\text { Conceptions }\end{array}$ & $\begin{array}{c}0.400 \\
(0.000)\end{array}$ & $\begin{array}{c}0.416 \\
(0.000)\end{array}$ & $\begin{array}{c}0.502 \\
(0.000)\end{array}$ & $\begin{array}{c}0.462 \\
(0.000)\end{array}$ & $\begin{array}{c}0.395 \\
(0.000)\end{array}$ & $\begin{array}{c}0.156 \\
(0.002)\end{array}$ & $\begin{array}{c}0.007 \\
(0.886)\end{array}$ & $\begin{array}{c}0.169 \\
(0.001)\end{array}$ & $\begin{array}{c}0.183 \\
(0.000)\end{array}$ & $\begin{array}{c}0.288 \\
(0.000)\end{array}$ & $\begin{array}{c}0.036 \\
(0.491)\end{array}$ & $\begin{array}{c}0.334 \\
(0.000)\end{array}$ & $\begin{array}{c}0.462 \\
(0.000)\end{array}$ & & & & \\
\hline 15 Crimes by Deception & $\begin{array}{c}-0.048 \\
(0.350)\end{array}$ & $\begin{array}{c}0.223 \\
(0.000)\end{array}$ & $\begin{array}{c}0.229 \\
(0.000)\end{array}$ & $\begin{array}{c}0.239 \\
(0.000)\end{array}$ & $\begin{array}{c}0.205 \\
(0.000)\end{array}$ & $\begin{array}{c}0.443 \\
(0.000)\end{array}$ & $\begin{array}{c}0.241 \\
(0.000)\end{array}$ & $\begin{array}{c}0.457 \\
(0.000)\end{array}$ & $\begin{array}{c}0.486 \\
(0.000)\end{array}$ & $\begin{array}{c}0.376 \\
(0.000)\end{array}$ & $\begin{array}{c}0.389 \\
(0.000)\end{array}$ & $\begin{array}{c}0.273 \\
(0.000)\end{array}$ & $\begin{array}{c}0.417 \\
(0.000)\end{array}$ & $\begin{array}{c}0.421 \\
(0.000)\end{array}$ & & & \\
\hline 16 Non-Sexual Violence & $\begin{array}{c}-0.191 \\
(0.000)\end{array}$ & $\begin{array}{c}0.226 \\
(0.000)\end{array}$ & $\begin{array}{c}0.167 \\
(0.001)\end{array}$ & $\begin{array}{c}0.213 \\
(0.000)\end{array}$ & $\begin{array}{c}0.014 \\
(0.786)\end{array}$ & $\begin{array}{c}0.695 \\
(0.000)\end{array}$ & $\begin{array}{c}0.534 \\
(0.000)\end{array}$ & $\begin{array}{c}0.604 \\
(0.000)\end{array}$ & $\begin{array}{c}0.731 \\
(0.000)\end{array}$ & $\begin{array}{c}0.451 \\
(0.000)\end{array}$ & $\begin{array}{c}0.494 \\
(0.000)\end{array}$ & $\begin{array}{c}0.361 \\
(0.000)\end{array}$ & $\begin{array}{c}0.404 \\
(0.000)\end{array}$ & $\begin{array}{c}0.416 \\
(0.000)\end{array}$ & $\begin{array}{c}0.720 \\
(0.000)\end{array}$ & & \\
\hline $\begin{array}{l}17 \text { Trade Union } \\
\text { Membership }\end{array}$ & $\begin{array}{c}-0.151 \\
(0.003)\end{array}$ & $\begin{array}{l}-0.424 \\
(0.000)\end{array}$ & $\begin{array}{l}-0.287 \\
(0.000)\end{array}$ & $\begin{array}{l}-0.216 \\
(0.000)\end{array}$ & $\begin{array}{l}-0.427 \\
(0.000)\end{array}$ & $\begin{array}{c}0.339 \\
(0.000)\end{array}$ & $\begin{array}{c}0.325 \\
(0.000)\end{array}$ & $\begin{array}{c}0.281 \\
(0.000)\end{array}$ & $\begin{array}{c}0.354 \\
(0.000)\end{array}$ & $\begin{array}{c}0.002 \\
(0.974)\end{array}$ & $\begin{array}{c}0.374 \\
(0.000)\end{array}$ & $\begin{array}{l}-0.137 \\
(0.008)\end{array}$ & $\begin{array}{c}-0.331 \\
(0.000)\end{array}$ & $\begin{array}{c}-0.281 \\
(0.000)\end{array}$ & $\begin{array}{l}-0.017 \\
(0.743)\end{array}$ & $\begin{array}{c}0.122 \\
(0.019)\end{array}$ & \\
\hline $\begin{array}{l}18 \text { Votes for Left of Centre } \\
\text { Parties }\end{array}$ & $\begin{array}{l}-0.122 \\
(0.018)\end{array}$ & $\begin{array}{l}-0.440 \\
(0.000)\end{array}$ & $\begin{array}{l}-0.429 \\
(0.000)\end{array}$ & $\begin{array}{l}-0.292 \\
(0.000)\end{array}$ & $\begin{array}{l}-0.534 \\
(0.000)\end{array}$ & $\begin{array}{l}-0.140 \\
(0.007)\end{array}$ & $\begin{array}{c}0.081 \\
(0.118)\end{array}$ & $\begin{array}{l}-0.189 \\
(0.000)\end{array}$ & $\begin{array}{l}-0.129 \\
(0.013)\end{array}$ & $\begin{array}{l}-0.292 \\
(0.000)\end{array}$ & $\begin{array}{l}-0.082 \\
(0.113)\end{array}$ & $\begin{array}{l}-0.306 \\
(0.000)\end{array}$ & $\begin{array}{l}-0.681 \\
(0.000)\end{array}$ & $\begin{array}{l}-0.584 \\
(0.000)\end{array}$ & $\begin{array}{l}-0.432 \\
(0.000)\end{array}$ & $\begin{array}{l}-0.397 \\
(0.000)\end{array}$ & $\begin{array}{c}0.555 \\
(0.000)\end{array}$ \\
\hline
\end{tabular}

$\mathrm{p}$-values in parentheses 
Table A3: Correlation Matrix for All Measures

\begin{tabular}{|c|c|c|c|c|c|c|c|c|c|c|c|c|c|c|c|c|c|c|}
\hline & $\begin{array}{c}1 \\
\text { Existing } \\
\text { Entre’ }\end{array}$ & 2 & 3 & 4 & 5 & 6 & 7 & 8 & 9 & 10 & 11 & 12 & 13 & 14 & 15 & 16 & 17 & 18 \\
\hline $\begin{array}{l}2 \mathrm{New} \\
\text { Entrepreneurship }\end{array}$ & $\begin{array}{c}0.776 \\
(0.000)\end{array}$ & & & & & & & & & & & & & & & & & \\
\hline 3 Institutions & $\begin{array}{c}0.116 \\
(0.025)\end{array}$ & $\begin{array}{c}0.309 \\
(0.000)\end{array}$ & & & & & & & & & & & & & & & & \\
\hline $\begin{array}{l}4 \text { Population } \\
\text { Growth }\end{array}$ & $\begin{array}{l}-0.137 \\
(0.008)\end{array}$ & $\begin{array}{c}0.180 \\
(0.000)\end{array}$ & $\begin{array}{c}0.183 \\
(0.000)\end{array}$ & & & & & & & & & & & & & & & \\
\hline 5 Growth Income & $\begin{array}{l}-0.131 \\
(0.011)\end{array}$ & $\begin{array}{l}-0.164 \\
(0.001)\end{array}$ & $\begin{array}{c}0.012 \\
(0.814)\end{array}$ & $\begin{array}{c}0.034 \\
(0.511)\end{array}$ & & & & & & & & & & & & & & \\
\hline $\begin{array}{l}6 \text { Change in } \\
\text { Unemployment }\end{array}$ & $\begin{array}{l}-0.621 \\
(0.000)\end{array}$ & $\begin{array}{l}-0.377 \\
(0.000)\end{array}$ & $\begin{array}{l}-0.089 \\
(0.087)\end{array}$ & $\begin{array}{c}0.109 \\
(0.035)\end{array}$ & $\begin{array}{c}0.005 \\
(0.921)\end{array}$ & & & & & & & & & & & & & \\
\hline $\begin{array}{l}7 \text { Industrial } \\
\text { Specialization }\end{array}$ & $\begin{array}{c}0.058 \\
(0.264)\end{array}$ & $\begin{array}{c}0.125 \\
(0.015)\end{array}$ & $\begin{array}{l}-0.043 \\
(0.411)\end{array}$ & $\begin{array}{c}0.155 \\
(0.003)\end{array}$ & $\begin{array}{c}0.026 \\
(0.618)\end{array}$ & $\begin{array}{l}-0.051 \\
(0.327)\end{array}$ & & & & & & & & & & & & \\
\hline $\begin{array}{l}8 \text { Industrial } \\
\text { Diversity }\end{array}$ & $\begin{array}{l}-0.007 \\
(0.892)\end{array}$ & $\begin{array}{l}-0.232 \\
(0.000)\end{array}$ & $\begin{array}{l}-0.183 \\
(0.000)\end{array}$ & $\begin{array}{l}-0.234 \\
(0.000)\end{array}$ & $\begin{array}{c}0.012 \\
(0.823)\end{array}$ & $\begin{array}{c}0.085 \\
(0.100)\end{array}$ & $\begin{array}{l}-0.452 \\
(0.000)\end{array}$ & & & & & & & & & & & \\
\hline 9 Managers & $\begin{array}{c}0.489 \\
(0.000)\end{array}$ & $\begin{array}{c}0.381 \\
(0.000)\end{array}$ & $\begin{array}{c}0.050 \\
(0.336)\end{array}$ & $\begin{array}{l}-0.187 \\
(0.000)\end{array}$ & $\begin{array}{l}-0.113 \\
(0.029)\end{array}$ & $\begin{array}{l}-0.410 \\
(0.000)\end{array}$ & $\begin{array}{l}-0.040 \\
(0.446)\end{array}$ & $\begin{array}{c}0.007 \\
(0.886)\end{array}$ & & & & & & & & & & \\
\hline 10 Professionals & $\begin{array}{c}0.363 \\
(0.000)\end{array}$ & $\begin{array}{c}0.500 \\
(0.000)\end{array}$ & $\begin{array}{c}0.162 \\
(0.002)\end{array}$ & $\begin{array}{c}0.199 \\
(0.000)\end{array}$ & $\begin{array}{c}0.008 \\
(0.881)\end{array}$ & $\begin{array}{l}-0.385 \\
(0.000)\end{array}$ & $\begin{array}{c}0.115 \\
(0.026)\end{array}$ & $\begin{array}{l}-0.370 \\
(0.000)\end{array}$ & $\begin{array}{c}0.174 \\
(0.001)\end{array}$ & & & & & & & & & \\
\hline 11 Prime Age & $\begin{array}{c}0.176 \\
(0.001)\end{array}$ & $\begin{array}{c}0.511 \\
(0.000)\end{array}$ & $\begin{array}{c}0.252 \\
(0.000)\end{array}$ & $\begin{array}{c}0.397 \\
(0.000)\end{array}$ & $\begin{array}{l}-0.050 \\
(0.338)\end{array}$ & $\begin{array}{l}-0.030 \\
(0.563)\end{array}$ & $\begin{array}{c}0.070 \\
(0.174)\end{array}$ & $\begin{array}{l}-0.100 \\
(0.053)\end{array}$ & $\begin{array}{c}0.112 \\
(0.031)\end{array}$ & $\begin{array}{c}0.365 \\
(0.000)\end{array}$ & & & & & & & & \\
\hline 12 In Education & $\begin{array}{l}-0.322 \\
(0.000)\end{array}$ & $\begin{array}{l}-0.091 \\
(0.079)\end{array}$ & $\begin{array}{l}-0.031 \\
(0.550)\end{array}$ & $\begin{array}{c}0.339 \\
(0.000)\end{array}$ & $\begin{array}{c}0.052 \\
(0.318)\end{array}$ & $\begin{array}{c}0.142 \\
(0.006)\end{array}$ & $\begin{array}{c}0.051 \\
(0.324)\end{array}$ & $\begin{array}{l}-0.268 \\
(0.000)\end{array}$ & $\begin{array}{l}-0.228 \\
(0.000)\end{array}$ & $\begin{array}{c}0.183 \\
(0.000)\end{array}$ & $\begin{array}{c}0.044 \\
(0.393)\end{array}$ & & & & & & & \\
\hline 13 In Poor Health & $\begin{array}{l}-0.551 \\
(0.000)\end{array}$ & $\begin{array}{l}-0.496 \\
(0.000)\end{array}$ & $\begin{array}{l}-0.295 \\
(0.000)\end{array}$ & $\begin{array}{l}-0.060 \\
(0.249)\end{array}$ & $\begin{array}{c}0.065 \\
(0.212)\end{array}$ & $\begin{array}{c}0.556 \\
(0.000)\end{array}$ & $\begin{array}{c}0.096 \\
(0.064)\end{array}$ & $\begin{array}{l}-0.012 \\
(0.817)\end{array}$ & $\begin{array}{l}-0.435 \\
(0.000)\end{array}$ & $\begin{array}{l}-0.416 \\
(0.000)\end{array}$ & $\begin{array}{l}-0.332 \\
(0.000)\end{array}$ & $\begin{array}{c}0.160 \\
(0.002)\end{array}$ & & & & & & \\
\hline 14 Pensioners & $\begin{array}{c}0.185 \\
(0.000)\end{array}$ & $\begin{array}{l}-0.248 \\
(0.000)\end{array}$ & $\begin{array}{l}-0.198 \\
(0.000)\end{array}$ & $\begin{array}{l}-0.583 \\
(0.000)\end{array}$ & $\begin{array}{l}-0.026 \\
(0.610)\end{array}$ & $\begin{array}{l}-0.216 \\
(0.000)\end{array}$ & $\begin{array}{l}-0.142 \\
(0.006)\end{array}$ & $\begin{array}{c}0.281 \\
(0.000)\end{array}$ & $\begin{array}{c}0.184 \\
(0.000)\end{array}$ & $\begin{array}{l}-0.330 \\
(0.000)\end{array}$ & $\begin{array}{l}-0.691 \\
(0.000)\end{array}$ & $\begin{array}{l}-0.588 \\
(0.000)\end{array}$ & $\begin{array}{c}0.022 \\
(0.665)\end{array}$ & & & & & \\
\hline $\begin{array}{l}15 \text { Engagement } \\
\text { with Education } \\
\text { and Work }\end{array}$ & $\begin{array}{c}0.301 \\
(0.000)\end{array}$ & $\begin{array}{c}0.233 \\
(0.000)\end{array}$ & $\begin{array}{c}0.244 \\
(0.000)\end{array}$ & $\begin{array}{l}-0.081 \\
(0.117)\end{array}$ & $\begin{array}{l}-0.017 \\
(0.736)\end{array}$ & $\begin{array}{l}-0.329 \\
(0.000)\end{array}$ & $\begin{array}{l}-0.203 \\
(0.000)\end{array}$ & $\begin{array}{c}0.289 \\
(0.000)\end{array}$ & $\begin{array}{c}0.284 \\
(0.000)\end{array}$ & $\begin{array}{c}0.061 \\
(0.242)\end{array}$ & $\begin{array}{c}0.278 \\
(0.000)\end{array}$ & $\begin{array}{l}-0.269 \\
(0.000)\end{array}$ & $\begin{array}{l}-0.669 \\
(0.000)\end{array}$ & $\begin{array}{c}0.102 \\
(0.050)\end{array}$ & & & & \\
\hline $\begin{array}{l}16 \text { Social } \\
\text { Cohesion }\end{array}$ & $\begin{array}{l}-0.149 \\
(0.004)\end{array}$ & $\begin{array}{l}-0.534 \\
(0.000)\end{array}$ & $\begin{array}{l}-0.290 \\
(0.000)\end{array}$ & $\begin{array}{l}-0.632 \\
(0.000)\end{array}$ & $\begin{array}{c}0.003 \\
(0.947)\end{array}$ & $\begin{array}{c}0.099 \\
(0.055)\end{array}$ & $\begin{array}{l}-0.251 \\
(0.000)\end{array}$ & $\begin{array}{c}0.471 \\
(0.000)\end{array}$ & $\begin{array}{c}0.007 \\
(0.894)\end{array}$ & $\begin{array}{l}-0.467 \\
(0.000)\end{array}$ & $\begin{array}{l}-0.526 \\
(0.000)\end{array}$ & $\begin{array}{l}-0.426 \\
(0.000)\end{array}$ & $\begin{array}{c}0.217 \\
(0.000)\end{array}$ & $\begin{array}{c}0.687 \\
(0.000)\end{array}$ & $\begin{array}{c}0.078 \\
(0.133)\end{array}$ & & & \\
\hline 17 Femininity & $\begin{array}{c}0.075 \\
(0.148) \\
\end{array}$ & $\begin{array}{l}-0.311 \\
(0.000)\end{array}$ & $\begin{array}{l}-0.208 \\
(0.000)\end{array}$ & $\begin{array}{l}-0.469 \\
(0.000)\end{array}$ & $\begin{array}{l}-0.037 \\
(0.470)\end{array}$ & $\begin{array}{l}-0.145 \\
(0.005)\end{array}$ & $\begin{array}{l}-0.204 \\
(0.000)\end{array}$ & $\begin{array}{c}0.350 \\
(0.000)\end{array}$ & $\begin{array}{c}0.099 \\
(0.055)\end{array}$ & $\begin{array}{l}-0.232 \\
(0.000)\end{array}$ & $\begin{array}{l}-0.457 \\
(0.000)\end{array}$ & $\begin{array}{l}-0.418 \\
(0.000)\end{array}$ & $\begin{array}{l}-0.044 \\
(0.400)\end{array}$ & $\begin{array}{c}0.712 \\
(0.000)\end{array}$ & $\begin{array}{c}0.211 \\
(0.000)\end{array}$ & $\begin{array}{c}0.686 \\
(0.000)\end{array}$ & & \\
\hline
\end{tabular}

p-values in parenthesis 
Table A3: Continued

\begin{tabular}{|c|c|c|c|c|c|c|c|c|c|c|c|c|c|c|c|c|c|c|}
\hline & $\begin{array}{c}1 \\
\text { Existing } \\
\text { Entre’ }\end{array}$ & 2 & 3 & 4 & 5 & 6 & 7 & 8 & 9 & 10 & 11 & 12 & 13 & 14 & 15 & 16 & 17 & 18 \\
\hline $\begin{array}{l}18 \text { Adherence } \\
\text { to Social Rules }\end{array}$ & $\begin{array}{c}0.380 \\
(0.000)\end{array}$ & $\begin{array}{c}0.011 \\
(0.827)\end{array}$ & $\begin{array}{c}-0.050 \\
(0.338)\end{array}$ & $\begin{array}{c}-0.398 \\
(0.000)\end{array}$ & $\begin{array}{l}-0.057 \\
(0.269)\end{array}$ & $\begin{array}{l}-0.483 \\
(0.000)\end{array}$ & $\begin{array}{c}-0.179 \\
(0.000)\end{array}$ & $\begin{array}{c}0.315 \\
(0.000)\end{array}$ & $\begin{array}{c}0.372 \\
(0.000)\end{array}$ & $\begin{array}{c}0.015 \\
(0.776)\end{array}$ & $\begin{array}{c}-0.219 \\
(0.000)\end{array}$ & $\begin{array}{c}-0.392 \\
(0.000)\end{array}$ & $\begin{array}{c}-0.475 \\
(0.000)\end{array}$ & $\begin{array}{c}0.561 \\
(0.000)\end{array}$ & $\begin{array}{c}0.453 \\
(0.000)\end{array}$ & $\begin{array}{c}0.444 \\
(0.000)\end{array}$ & $\begin{array}{c}0.568 \\
(0.000)\end{array}$ & \\
\hline $\begin{array}{l}19 \text { Collective } \\
\text { Action }\end{array}$ & $\begin{array}{l}-0.472 \\
(0.000)\end{array}$ & $\begin{array}{l}-0.441 \\
(0.000)\end{array}$ & $\begin{array}{l}-0.451 \\
(0.000)\end{array}$ & $\begin{array}{l}-0.087 \\
(0.094)\end{array}$ & $\begin{array}{c}0.110 \\
(0.033)\end{array}$ & $\begin{array}{c}0.444 \\
(0.000)\end{array}$ & $\begin{array}{c}0.129 \\
(0.013)\end{array}$ & $\begin{array}{c}0.003 \\
(0.947)\end{array}$ & $\begin{array}{l}-0.376 \\
(0.000)\end{array}$ & $\begin{array}{c}-0.194 \\
(0.000)\end{array}$ & $\begin{array}{l}-0.185 \\
(0.000)\end{array}$ & $\begin{array}{c}0.285 \\
(0.000)\end{array}$ & $\begin{array}{c}0.741 \\
(0.000)\end{array}$ & $\begin{array}{l}-0.152 \\
(0.003)\end{array}$ & $\begin{array}{l}-0.544 \\
(0.000)\end{array}$ & $\begin{array}{c}0.205 \\
(0.000)\end{array}$ & $\begin{array}{l}-0.120 \\
(0.020)\end{array}$ & $\begin{array}{l}-0.449 \\
(0.000)\end{array}$ \\
\hline
\end{tabular}

$\mathrm{p}$-values in parenthesis 
Table A4: Correlations for Individual Variables

\begin{tabular}{|c|c|c|c|c|c|}
\hline & 15 & 16 & 17 & 18 & 19 \\
\hline 1 Existing Entrepreneurship & $\begin{array}{c}0.361 \\
(0.000)\end{array}$ & $\begin{array}{c}-0.014 \\
(0.780)\end{array}$ & $\begin{array}{c}0.117 \\
(0.024)\end{array}$ & $\begin{array}{c}0.210 \\
(0.000)\end{array}$ & $\begin{array}{l}-0.537 \\
(0.000)\end{array}$ \\
\hline 2 New Entrepreneurship & $\begin{array}{c}0.387 \\
(0.000)\end{array}$ & $\begin{array}{l}-0.446 \\
(0.000)\end{array}$ & $\begin{array}{l}-0.202 \\
(0.000)\end{array}$ & $\begin{array}{l}-0.135 \\
(0.009)\end{array}$ & $\begin{array}{l}-0.331 \\
(0.000)\end{array}$ \\
\hline 3 Institutions & $\begin{array}{c}0.279 \\
(0.000)\end{array}$ & $\begin{array}{l}-0.304 \\
(0.000)\end{array}$ & $\begin{array}{l}-0.128 \\
(0.014)\end{array}$ & $\begin{array}{l}-0.051 \\
(0.326)\end{array}$ & $\begin{array}{l}-0.253 \\
(0.000)\end{array}$ \\
\hline 4 Population Growth & $\begin{array}{c}0.027 \\
(0.599)\end{array}$ & $\begin{array}{l}-0.641 \\
(0.000)\end{array}$ & $\begin{array}{l}-0.276 \\
(0.000)\end{array}$ & $\begin{array}{l}-0.348 \\
(0.000)\end{array}$ & $\begin{array}{c}0.139 \\
(0.007)\end{array}$ \\
\hline 5 Growth Income & $\begin{array}{c}-0.028 \\
(0.587)\end{array}$ & $\begin{array}{l}-0.007 \\
(0.890)\end{array}$ & $\begin{array}{c}0.035 \\
(0.503)\end{array}$ & $\begin{array}{c}0.006 \\
(0.901)\end{array}$ & $\begin{array}{c}0.111 \\
(0.033)\end{array}$ \\
\hline 6 Change in Unemployment & $\begin{array}{l}-0.354 \\
(0.000)\end{array}$ & $\begin{array}{l}-0.030 \\
(0.568)\end{array}$ & $\begin{array}{l}-0.161 \\
(0.002)\end{array}$ & $\begin{array}{c}-0.374 \\
(0.000)\end{array}$ & $\begin{array}{c}0.490 \\
(0.000)\end{array}$ \\
\hline 7 Industrial Specialization & $\begin{array}{l}-0.110 \\
(0.034)\end{array}$ & $\begin{array}{l}-0.213 \\
(0.000)\end{array}$ & $\begin{array}{l}-0.176 \\
(0.001)\end{array}$ & $\begin{array}{l}-0.101 \\
(0.050)\end{array}$ & $\begin{array}{c}0.178 \\
(0.001)\end{array}$ \\
\hline 8 Industrial Diversity & $\begin{array}{c}0.110 \\
(0.034)\end{array}$ & $\begin{array}{c}0.435 \\
(0.000)\end{array}$ & $\begin{array}{c}0.224 \\
(0.000)\end{array}$ & $\begin{array}{c}0.212 \\
(0.000)\end{array}$ & $\begin{array}{l}-0.118 \\
(0.022)\end{array}$ \\
\hline 9 Managers & $\begin{array}{c}0.326 \\
(0.000)\end{array}$ & $\begin{array}{c}0.079 \\
(0.127)\end{array}$ & $\begin{array}{c}0.088 \\
(0.089)\end{array}$ & $\begin{array}{c}0.199 \\
(0.000)\end{array}$ & $\begin{array}{l}-0.439 \\
(0.000)\end{array}$ \\
\hline 10 Professionals & $\begin{array}{c}0.232 \\
(0.000)\end{array}$ & $\begin{array}{c}-0.392 \\
(0.000)\end{array}$ & $\begin{array}{l}-0.115 \\
(0.026)\end{array}$ & $\begin{array}{l}-0.076 \\
(0.144)\end{array}$ & $\begin{array}{l}-0.149 \\
(0.004)\end{array}$ \\
\hline 11 Prime Age & $\begin{array}{c}0.360 \\
(0.000)\end{array}$ & $\begin{array}{l}-0.540 \\
(0.000)\end{array}$ & $\begin{array}{l}-0.387 \\
(0.000)\end{array}$ & $\begin{array}{l}-0.258 \\
(0.000)\end{array}$ & $\begin{array}{c}0.031 \\
(0.551)\end{array}$ \\
\hline 12 In Education & $\begin{array}{l}-0.110 \\
(0.034)\end{array}$ & $\begin{array}{l}-0.471 \\
(0.000)\end{array}$ & $\begin{array}{l}-0.300 \\
(0.000)\end{array}$ & $\begin{array}{l}-0.309 \\
(0.000)\end{array}$ & $\begin{array}{c}0.333 \\
(0.000)\end{array}$ \\
\hline 13 In Poor Health & $\begin{array}{l}-0.563 \\
(0.000)\end{array}$ & $\begin{array}{c}0.141 \\
(0.006)\end{array}$ & $\begin{array}{l}-0.121 \\
(0.019)\end{array}$ & $\begin{array}{l}-0.238 \\
(0.000)\end{array}$ & $\begin{array}{c}0.677 \\
(0.000)\end{array}$ \\
\hline 14 Pensioners & $\begin{array}{l}-0.061 \\
(0.242)\end{array}$ & $\begin{array}{c}0.739 \\
(0.000)\end{array}$ & $\begin{array}{c}0.548 \\
(0.000)\end{array}$ & $\begin{array}{c}0.509 \\
(0.000)\end{array}$ & $\begin{array}{l}-0.374 \\
(0.000)\end{array}$ \\
\hline $\begin{array}{l}15 \text { Secondary School } \\
\text { Absences (inverse) }\end{array}$ & 1.000 & $\begin{array}{l}-0.191 \\
(0.000)\end{array}$ & $\begin{array}{l}-0.011 \\
(0.836)\end{array}$ & $\begin{array}{c}0.205 \\
(0.000)\end{array}$ & $\begin{array}{l}-0.534 \\
(0.000)\end{array}$ \\
\hline 16 Ethnic Similarity & $\begin{array}{l}-0.191 \\
(0.000)\end{array}$ & 1.000 & $\begin{array}{c}0.497 \\
(0.000)\end{array}$ & $\begin{array}{c}0.486 \\
(0.000)\end{array}$ & $\begin{array}{l}-0.129 \\
(0.013)\end{array}$ \\
\hline $\begin{array}{l}17 \text { Female Employment } \\
\text { which is Part-Time }\end{array}$ & $\begin{array}{l}-0.011 \\
(0.836)\end{array}$ & $\begin{array}{c}0.497 \\
(0.000)\end{array}$ & 1.000 & $\begin{array}{c}0.376 \\
(0.000)\end{array}$ & $\begin{array}{l}-0.292 \\
(0.000)\end{array}$ \\
\hline $\begin{array}{l}18 \text { Crimes by Deception } \\
\text { (inverse) }\end{array}$ & $\begin{array}{c}0.205 \\
(0.000)\end{array}$ & $\begin{array}{c}0.486 \\
(0.000)\end{array}$ & $\begin{array}{c}0.376 \\
(0.000)\end{array}$ & 1.000 & $\begin{array}{l}-0.432 \\
(0.000)\end{array}$ \\
\hline $\begin{array}{l}19 \text { Voting for Left of Centre } \\
\text { Parties }\end{array}$ & $\begin{array}{l}-0.534 \\
(0.000)\end{array}$ & $\begin{array}{l}-0.129 \\
(0.013)\end{array}$ & $\begin{array}{l}-0.292 \\
(0.000)\end{array}$ & $\begin{array}{l}-0.432 \\
(0.000)\end{array}$ & 1.000 \\
\hline
\end{tabular}

p-values in parentheses 
Table A5: OLS Regressions of Formal Institutions

\begin{tabular}{|c|c|c|c|c|c|}
\hline & Model 11 & Model 12 & Model 13 & Model 14 & Model 15 \\
\hline $\begin{array}{l}\text { Engagement with } \\
\text { Education and Work }\end{array}$ & $\begin{array}{l}0.0443 \\
(0.014)\end{array}$ & & & & \\
\hline Social Cohesion & & $\begin{array}{l}-0.0250 \\
(0.273)\end{array}$ & & & \\
\hline $\begin{array}{l}\text { Femininity and Caring } \\
\text { Activities }\end{array}$ & & & $\begin{array}{l}-0.0213 \\
(0.199)\end{array}$ & & \\
\hline $\begin{array}{l}\text { Adherence to Social } \\
\text { Rules }\end{array}$ & & & & $\begin{array}{l}-0.0141 \\
(0.447)\end{array}$ & \\
\hline Collective Activities & & & & & $\begin{array}{l}-0.1294 \\
(0.000)\end{array}$ \\
\hline $\begin{array}{l}\text { Existing } \\
\text { Entrepreneurship }\end{array}$ & $\begin{array}{r}-0.7433 \\
(0.001)\end{array}$ & $\begin{array}{l}-0.7898 \\
(0.000)\end{array}$ & $\begin{array}{l}-0.7740 \\
(0.000)\end{array}$ & $\begin{array}{l}-0.8058 \\
(0.000)\end{array}$ & $\begin{array}{l}-0.8104 \\
(0.000)\end{array}$ \\
\hline New Entrepreneurship & $\begin{array}{l}0.0481 \\
(0.000)\end{array}$ & $\begin{array}{l}0.0445 \\
(0.000)\end{array}$ & $\begin{array}{l}0.0450 \\
(0.000)\end{array}$ & $\begin{array}{l}0.0481 \\
(0.000)\end{array}$ & $\begin{array}{l}0.0467 \\
(0.000)\end{array}$ \\
\hline Population Growth & $\begin{array}{l}0.4301 \\
(0.214)\end{array}$ & $\begin{array}{l}0.1272 \\
(0.751)\end{array}$ & $\begin{array}{l}0.2514 \\
(0.478)\end{array}$ & $\begin{array}{l}0.2812 \\
(0.432)\end{array}$ & $\begin{array}{l}-0.0264 \\
(0.936)\end{array}$ \\
\hline Income Growth & $\begin{array}{l}0.2878 \\
(0.216)\end{array}$ & $\begin{array}{l}0.2870 \\
(0.221)\end{array}$ & $\begin{array}{l}0.2791 \\
(0.234)\end{array}$ & $\begin{array}{l}0.2923 \\
(0.213)\end{array}$ & $\begin{array}{l}0.4274 \\
(0.052)\end{array}$ \\
\hline $\begin{array}{l}\text { Change in } \\
\text { Unemployment }\end{array}$ & $\begin{array}{l}0.0010 \\
(0.982)\end{array}$ & $\begin{array}{r}-0.0010 \\
(0.982)\end{array}$ & $\begin{array}{l}-0.0079 \\
(0.859)\end{array}$ & $\begin{array}{l}-0.0127 \\
(0.782)\end{array}$ & $\begin{array}{l}0.0165 \\
(0.693)\end{array}$ \\
\hline Industrial Specialization & $\begin{array}{l}-0.3688 \\
(0.015)\end{array}$ & $\begin{array}{l}-0.3854 \\
(0.012)\end{array}$ & $\begin{array}{l}-0.3868 \\
(0.011)\end{array}$ & $\begin{array}{r}-0.3730 \\
(0.014)\end{array}$ & $\begin{array}{l}-0.2028 \\
(0.160)\end{array}$ \\
\hline Industrial Diversity & $\begin{array}{r}-1.1124 \\
(0.001)\end{array}$ & $\begin{array}{l}-0.7961 \\
(0.012)\end{array}$ & $\begin{array}{l}-0.8458 \\
(0.006)\end{array}$ & $\begin{array}{r}-0.8345 \\
(0.008)\end{array}$ & $\begin{array}{l}-0.6770 \\
(0.019)\end{array}$ \\
\hline Proportion in Education & $\begin{array}{l}-0.0122 \\
(0.030)\end{array}$ & $\begin{array}{l}-0.0170 \\
(0.005)\end{array}$ & $\begin{array}{l}-0.0166 \\
(0.004)\end{array}$ & $\begin{array}{l}-0.0153 \\
(0.007)\end{array}$ & $\begin{array}{l}-0.0027 \\
(0.626)\end{array}$ \\
\hline $\begin{array}{l}\text { Proportion in Poor } \\
\text { Health }\end{array}$ & $\begin{array}{l}-0.0160 \\
(0.083)\end{array}$ & $\begin{array}{l}-0.0295 \\
(0.000)\end{array}$ & $\begin{array}{l}-0.0308 \\
(0.000)\end{array}$ & $\begin{array}{l}-0.0326 \\
(0.000)\end{array}$ & $\begin{array}{l}0.0064 \\
(0.451)\end{array}$ \\
\hline Constant & $\begin{array}{l}2.0329 \\
(0.000)\end{array}$ & $\begin{array}{l}2.0751 \\
(0.000)\end{array}$ & $\begin{array}{l}2.1085 \\
(0.000)\end{array}$ & $\begin{array}{l}2.0819 \\
(0.000)\end{array}$ & $\begin{array}{l}1.3124 \\
(0.000)\end{array}$ \\
\hline$N$ & 374 & 374 & 374 & 374 & 374 \\
\hline F-test & $\begin{array}{c}11.2 \\
(0.000)\end{array}$ & $\begin{array}{c}10.6 \\
(0.000)\end{array}$ & $\begin{array}{c}10.7 \\
(0.000)\end{array}$ & $\begin{array}{c}10.5 \\
(0.000)\end{array}$ & $\begin{array}{l}17.0 \\
(0.000)\end{array}$ \\
\hline$R^{2}$ & 0.236 & 0.226 & 0.227 & 0.225 & 0.319 \\
\hline
\end{tabular}

$\mathrm{p}$-values in parentheses 
Table A6: OLS Regressions of Cultural Components

\begin{tabular}{|c|c|c|c|c|c|}
\hline & $\begin{array}{l}\text { Engagement } \\
\text { with } \\
\text { Education } \\
\text { and Work } \\
\end{array}$ & $\begin{array}{c}\text { Social } \\
\text { Cohesion }\end{array}$ & $\begin{array}{c}\text { Femininity } \\
\text { and } \\
\text { Caring } \\
\text { Activities }\end{array}$ & $\begin{array}{c}\text { Adherence } \\
\text { to Social } \\
\text { Rules } \\
\end{array}$ & $\begin{array}{c}\text { Collective } \\
\text { Action }\end{array}$ \\
\hline Existing Entrepreneurship & $\begin{array}{c}-0.6242 \\
(0.450)\end{array}$ & $\begin{array}{l}1.0681 \\
(0.036)\end{array}$ & $\begin{array}{l}1.3435 \\
(0.042)\end{array}$ & $\begin{array}{l}1.8974 \\
(0.006)\end{array}$ & $\begin{array}{c}-0.4416 \\
(0.526)\end{array}$ \\
\hline New Entrepreneurship & $\begin{array}{l}0.0879 \\
(0.035)\end{array}$ & $\begin{array}{c}-0.1704 \\
(0.000)\end{array}$ & $\begin{array}{c}-0.1235 \\
(0.000)\end{array}$ & $\begin{array}{c}-0.0823 \\
(0.018)\end{array}$ & $\begin{array}{c}-0.1011 \\
(0.004)\end{array}$ \\
\hline Institutions & $\begin{array}{l}0.9047 \\
(0.000)\end{array}$ & $\begin{array}{l}-0.0419 \\
(0.712)\end{array}$ & $\begin{array}{c}-0.0389 \\
(0.791)\end{array}$ & $\begin{array}{l}0.2282 \\
(0.137)\end{array}$ & $\begin{array}{c}-1.4328 \\
(0.000)\end{array}$ \\
\hline Population Growth & $\begin{array}{c}-0.8508 \\
(0.523)\end{array}$ & $\begin{array}{c}-7.1818 \\
(0.000)\end{array}$ & $\begin{array}{l}-1.0094 \\
(0.341)\end{array}$ & $\begin{array}{l}-1.8410 \\
(0.098)\end{array}$ & $\begin{array}{l}-5.5829 \\
(0.000)\end{array}$ \\
\hline Income Growth & $\begin{array}{l}0.0790 \\
(0.926)\end{array}$ & $\begin{array}{l}-0.5380 \\
(0.305)\end{array}$ & $\begin{array}{c}-0.9038 \\
(0.183)\end{array}$ & $\begin{array}{l}-0.9061 \\
(0.202)\end{array}$ & $\begin{array}{l}1.1968 \\
(0.096)\end{array}$ \\
\hline Change in Unemployment & $\begin{array}{l}-0.7753 \\
(0.000)\end{array}$ & $\begin{array}{l}0.3101 \\
(0.001)\end{array}$ & $\begin{array}{l}-0.1060 \\
(0.373)\end{array}$ & $\begin{array}{l}-0.8826 \\
(0.000)\end{array}$ & $\begin{array}{l}0.6326 \\
(0.000)\end{array}$ \\
\hline Industrial Specialization & $\begin{array}{l}-0.6238 \\
(0.255)\end{array}$ & $\begin{array}{l}-0.2221 \\
(0.510)\end{array}$ & $\begin{array}{l}-0.5458 \\
(0.211)\end{array}$ & $\begin{array}{l}-0.4615 \\
(0.312)\end{array}$ & $\begin{array}{l}1.3635 \\
(0.003)\end{array}$ \\
\hline Industrial Diversity & $\begin{array}{l}7.5192 \\
(0.000)\end{array}$ & $\begin{array}{l}3.8314 \\
(0.000)\end{array}$ & $\begin{array}{l}2.0996 \\
(0.017)\end{array}$ & $\begin{array}{l}3.9490 \\
(0.000)\end{array}$ & $\begin{array}{l}-1.0358 \\
(0.262)\end{array}$ \\
\hline $\begin{array}{l}\text { Proportion in Pensioner Age } \\
\text { Group }\end{array}$ & $\begin{array}{l}0.0047 \\
(0.776)\end{array}$ & $\begin{array}{l}0.0929 \\
(0.000)\end{array}$ & $\begin{array}{l}0.1394 \\
(0.000)\end{array}$ & $\begin{array}{l}0.0784 \\
(0.000)\end{array}$ & $\begin{array}{c}-0.0841 \\
(0.000)\end{array}$ \\
\hline Constant & $\begin{array}{c}-5.5085 \\
(0.000)\end{array}$ & $\begin{array}{l}-3.6760 \\
(0.000)\end{array}$ & $\begin{array}{l}-3.3467 \\
(0.000)\end{array}$ & $\begin{array}{c}-3.4924 \\
(0.000)\end{array}$ & $\begin{array}{l}3.2345 \\
(0.000)\end{array}$ \\
\hline$N$ & 374 & 374 & 374 & 374 & 374 \\
\hline F-test & $\begin{array}{c}17.7 \\
(0.000)\end{array}$ & $\begin{array}{c}113.5 \\
(0.000)\end{array}$ & $\begin{array}{c}51.5 \\
(0.000)\end{array}$ & $\begin{array}{c}44.3 \\
(0.000)\end{array}$ & $\begin{array}{c}41.3 \\
(0.000)\end{array}$ \\
\hline$R^{2}$ & 0.305 & 0.737 & 0.560 & 0.523 & 0.506 \\
\hline
\end{tabular}

